\title{
Managing Engagement in an Emerging Economy Service
}

\begin{abstract}
Purpose - This study offers a better understanding of managing engagement in an emerging economy service. It explores the role of organisational climates for initiative and psychological safety as the key drivers of employee engagement (EE). It also examines the effects of EE on customer engagement (CE) and, in turn, on relationship commitment and switching intention.
\end{abstract}

Methodology - Data were collected through a structured survey of service employees and customers of 69 bank branches in Bangladesh using two survey instruments. Responses were collected from 156 employees and 316 customers. A dyadic data set was created by matching customer data with the corresponding employee data collected from each bank branch. Structural equation modelling (SEM) using AMOS (version 22.0) was employed for data analysis.

Findings - Organisational climates for initiative and psychological safety positively influence employee engagement (EE). In turn, EE significantly influences CE which has a significant impact on customer relationship commitment and switching intention.

Research limitation/implication - Future research could consider actual customer behaviour, such as repeat purchase, as the key outcome variable.

Practical implications - The findings emphasise that investment by service managers in organisational resources to facilitate favourable climates for initiative and psychological safety would engage employees at work, which would ultimately help to attain $\mathrm{CE}$ and commitment, and reduce switching intention.

Originality/value - This research extends the existing engagement literature with empirical evidence supporting two new EE drivers and two new CE outcomes. It offers a better understanding of managing engagement in the financial services industry of an emerging economy, focusing on the relationship chain from organisational climate to $\mathrm{EE}, \mathrm{CE}$ and customer-based outcomes.

Keywords: Employee engagement, Customer engagement, Organisational climate, Relationship commitment, Switching intention.

Paper type: Research paper 


\section{Introduction}

Engagement has received considerable academic interest from different streams in the literature including marketing (e.g., Kumar, 2013; Kumar et al., 2017) and management (e.g., Catteeuw et al., 2007). The term 'engagement' relates to the psychological presence of an individual that is accompanied by personally engaging behaviours and involves channelling personal energies into cognitive and emotional efforts (Chandler and Lusch, 2015; Schaufeli et al., 2002). Kumar and Pansari (2016) defined engagement as the attitude, behaviour and level of connectedness between a firm's employees and customers, as well as between a firm's customers, as they interact, co-create and develop solutions in the firm's favour, thus helping it to achieve competitive advantage. Therefore, the scope of engagement includes both employee engagement (EE) and customer engagement (CE). Engagement has become an important part of a firm's overall strategy. The reason is that firms with highly engaged employees have been found to enjoy an increase of more than $5 \%$ in operating margin and of $3 \%$ in net margin, compared to firms with highly disengaged employees (Menguc et al., 2013). Moreover, 72\% of highly engaged employees (compared to $27 \%$ of disengaged employees) believe they can positively affect customer service (Seijts and Crim, 2006), with this leading to obtaining customer satisfaction, loyalty, and firm profitability (Harter et al., 2002). This study investigates how to manage $\mathrm{EE}$ and $\mathrm{CE}$ together in an emerging economy service by offering a conceptual framework reflecting drivers of EE, the relationship between $\mathrm{EE}$ and $\mathrm{CE}$, and their simultaneous effect on customer-based outcomes. In doing so, the study addresses the following research gaps.

Firstly, the current study emphasises organisational climate as a key driver of employee engagement (EE). In particular, the organisational climates for initiative and psychological safety stimulate employees' learning behaviour and creative potential (Baer and Frese, 2003), with both helpful for innovation and skill development to solve problems at work. In the current dynamic and competitive business environment, the conventional top-down approach of 
specifying employee job descriptions is no longer realistic (Bakker and Demerouti, 2014; Griffin et al., 2007). Instead, employees are required to go beyond their current work roles, accommodating ongoing changes (Morrison and Phelps, 1999) and being able to accomplish their job objectives without following explicit instructions (Frese and Fay, 2001). Therefore, firms need employees who can take responsibility and come forward based on their own initiative (Morrison and Phelps, 1999). Firms also need to ensure a psychologically safe climate; otherwise, the chances of failure may inhibit employees from acting on their own initiative. Such a climate removes fears of taking initiative at work (Kahn, 1990). Therefore, these two elements of organisational climate - a climate for initiative and a climate for psychological safety - are complementary in nature and may influence employee involvement at work (Bock et al., 2005). However, research focusing on the effects of organisational climates for initiative and psychological safety on EE is relatively sparse. In an emerging economy context, these elements of organisational climate could play a vital role in engaging employees at work. The reason is that, unlike their counterparts in developed countries, employees of emerging economy service firms, in performing their duties, rely more on an organisational services climate that emphasises relevant practices, procedures and support behaviours within the organisation (Fung et al., 2017).

Secondly, past research provides evidence that customer service employees experience a decline in work engagement, whereas employees from other areas of firms achieve increased engagement (Gallup, 2013). This decline in EE may result in corresponding adverse effects on $\mathrm{CE}$ and customer-based outcomes. However, little is known about the simultaneous effects of EE and CE on customer-based outcomes. The lone study (Kumar and Pansari, 2016) that examined the simultaneous effects of $\mathrm{EE}$ and $\mathrm{CE}$ on firm performance conceptualised $\mathrm{EE}$ and CE based on outcome-focused dimensions, such as satisfaction, loyalty, commitment, performance, purchase, knowledge sharing and referral. This conceptualisation largely ignored the psychological aspects of both $\mathrm{EE}$ and $\mathrm{CE}$ and disregarded the underlying mechanism that 
relates to employee-customer interactions. Employees may differ in their responses to various organisational conditions (Spector, 2003), and employees who are passive towards their work environment are usually considered less desirable by firms (Lazarus, 1995). Having a better understanding of the underlying psychological mechanism relating to employee-customer interactions is therefore essential. This is particularly important in the emerging economy context as service firms in such economies place more emphasis on interpersonal relationships. Hence, the quality of interaction between service employees and customers acts as a key factor in service evaluation and its consequences (Riddle, 1992; Sharma et al., 2012). This underscores the need to better understand the psychological mechanisms of both employees and customers.

Thirdly, existing research highlights that engaged customers buy more than those who are disengaged (Sorenson and Adkins, 2014; Kumar et al., 2017). Engaged customers are thus likely to be more committed to the respective firm and have less switching intention compared to their disengaged counterparts. However, the effects of $\mathrm{CE}$ on customer commitment and switching intention are still unexplored. Specifically, no research to date has examined the effect of the EE-CE link on customer switching in banking services even though the average customer switching rate in banks, at 20\% is higher than for other services (e.g., internet service providers: 18\%, and mobile phone companies: 17\%) (LMA, 2018).

Fourthly, the studies reported in the existing literature on EE (e.g., Anaza and Rutherford, 2012; Breevaart et al., 2016) and CE (e.g., Beckers et al., 2018; Boardman et al., 2018) have been predominantly conducted in developed countries, such as the United States (USA), Canada, Europe and Australia. Only a handful of studies have independently explored EE (e.g., Beek et al., 2012) and CE (e.g., Parihar et al., 2019) in emerging economies, such as China and India. However, these studies have not addressed the research gaps identified above in the current work. Kumar and Pansari (2016) recommended more research on engagement, arguing that the relative impact of different aspects of EE and CE on firm performance may 
vary, based on the nature of the industry and the country. For example, unlike customers in developed countries, those in emerging economies have a relatively higher power distance and a stronger social hierarchy (Hofstede, 1991, 2001) and expect to be treated with respect by service employees (Sharma et al., 2012). Again, the banking services firms of an emerging economy, compared to those in developed countries, rely less on technology and involve a higher level of human interaction and personal contact between employees and customers (Malhotra et al., 2005).

The current study addresses the above-mentioned research gaps and contributes to the extant literature by offering two new drivers for EE (climates for initiative and psychological safety) and two new consequences of CE (relationship commitment and switching intention). It provides novel insights on the psychological mechanism of the EE-CE link. It also offers a parsimonious model that reflects a chain of relationships stemming from the climates for initiative and psychological safety through to EE, CE and customer outcomes such as relationship commitment and switching intention. The study tests the proposed model in a dyadic data set created by matching employee data with corresponding customer data collected from banking services firms of an emerging economy such as Bangladesh.

\section{Theoretical Background and Hypotheses}

\section{Employee Engagement and Its Drivers}

Employee engagement (EE) refers to the harnessing of organisation members (i.e., employees) to their work roles in which they deploy and express themselves physically, cognitively and emotionally during work role performances (Kahn, 1990; Simbula and Guglielmi, 2013). The underlying rationale is that when people are psychologically present at work, they stay attentive, connected and focused in their work role performances (Kahn, 1992). Schaufeli et al. (2002) mentioned that engaged employees' work-related mindset consists of three key components, namely, vigour, dedication and absorption. Vigour refers to the high levels of 
energy and mental resilience experienced by employees while working. It consists of the willingness to invest effort and persistence against difficulty. Dedication is the sense of significance, enthusiasm, inspiration, pride and challenge in the workplace. It reflects the extent of devotion of an employee at work. On the other hand, absorption refers to the employee having full concentration and being deeply engrossed at work, with time passing quickly and the employee feeling that it is difficult to be detached from work (Salanova et al., 2005).

The extant literature highlights that EE is influenced by several factors. For example, Demerouti et al. (2001a) mention that high job resources are likely to increase employee engagement. Saks and Gruman (2014) argue that EE is enhanced by a sustainable workload, feelings of choice and control, appropriate recognition and reward, a supportive work community, fairness and justice, and meaningful valued work. Table A in the Appendix provides a brief account of the drivers for EE, further indicating that no research to date has examined the effects of organisational climates for initiative and psychological safety on employee engagement (EE). Moreover, as shown in Table A, most of the existing EE literature has explored the drivers for EE in different industries, but not in the banking sector. Commercial banks experience high employee turnover and high employee stress (Gupta et al., 2015). The industry demands for employees to be involved in intense cognitive work and interactions with customers (Amiti and Wei, 2009; Kikuchi and Long, 2010). This underscores the need for more focus on employee engagement (EE) (Lockwood, 2007) and on having a favourable environment, in other words, having an organisational climate where employees can work with a proactive and entrepreneurial mindset.

The term 'organisational climate' refers to the aggregated psychological climate of an organisation that focuses on employees' perceptions of the work environment and its cognitive appraisal by individual employees in terms of its meanings to, and significance for, them (James et al., 1988). This term portrays the context within which all employees work and feel responsible for what they do (Frese et al., 2002) and, thus, is related to employees' perceptions 
of the degree to which their companies are organised to deliver the desired service quality (Schneider et al., 2009). Organisational climate is crucial in financial services as it influences employees' thoughts, feelings and behaviours (Bock et al., 2005); employees' adaptability, creativity and proactivity (Eldor and Harpaz, 2016); as well as employee-customer interactions (Clark, 2002). Kahn (1990) identified three psychological conditions of employees, namely, meaningfulness, safety and availability that are linked to their personal engagement at work. May et al. (2004) also argued in support of these three psychological conditions, considering them significantly related to employee engagement (EE). Menguc et al. (2017) noted that psychological climate is highly influential in the financial services industry. Building on the above arguments, this study considers two key components of the psychological climate of an organisation, namely, the 'climate for initiative' and the 'climate for psychological safety' as key drivers for EE in the financial services industry of an emerging economy. Employees in emerging economies experience job insecurity, as the demand for jobs is higher than job availability. In addition, firms in these economies are less concerned about employees' wellbeing, thus affecting their confidence and motivation at work (Mulinge and Mueller, 1998). Thus an emerging economy offers an interesting context in which to test the current study's hypotheses relating to the drivers and consequences of employee engagement (EE).

The term 'climate for initiative' refers to 'formal and informal organisational practices and procedures guiding and supporting a proactive, self-starting and persistent approach toward work' (Baer and Frese, 2003, p. 48). These organisational practices relate to facilitating an environment for decision making (Boudrias et al., 2010), leadership and innovation implementation behaviour (Michaelis et al., 2010). A favourable organisational climate for initiative helps in the successful implementation of human resource (HR) strategies, such as employee empowerment (Tremblay and Simard, 2005). Morrison and Phelps (1999) found that employees take initiative at work if they perceive a favourable climate that promotes new initiatives and that has top management support. In a commercial bank, employees are required 
to take initiative to interact and build relationships at a personal level. When an employee takes personal initiative, this means that $\mathrm{s} /$ he takes the risk of trying new things where $\mathrm{s} / \mathrm{he}$ has a chance to fail. Hence, the existence of a favourable environment that promotes initiative is essential in order to engage employees in their work dealing with customers. Baer and Frese (2003) supports this view, mentioning that, in an organiational climate for initiative, people exert more discretion which they apply to determine how they will do their work. The use of discretion also creates a feeling within employees that the outcomes achieved depended on their own efforts, initiatives and decisions rather than on the adequacy of instructions from the boss or on a job procedures manual (Hackman and Oldham, 1976).

On the other hand, the concept of the 'climate for psychological safety' can be used at both individual and team levels (Baer and Frese, 2003). At the individual level, this concept refers to the individual feeling that $\mathrm{s} / \mathrm{he}$ can display and employ his/her true self without fear of negative consequences to his/her self-image, status or career (Kahn, 1990). The individual will also feel safe if the climate within which s/he operates is open (Jourard, 1968) and supportive (Gibb, 1961). In a psychologically safe organisational climate, employees believe that their mistakes will not be held against them (Edmondson, 1996), and that they will not be tainted with unfavourable traits for using their initiative (Kahn, 1990). Psychological safety at the team level refers to 'a shared belief held by a work team that the team is safe for interpersonal risk taking' (Edmondson, 1999, p. 354). Baer and Frese (2003, p. 50) defined psychological safety from the organisational perspective as 'a work environment where employees are safe to speak up without being rejected or punished'. In such a situation, employees are likely to feel psychologically safe to undertake new initiatives, which will lead to their greater engagement at work. In a bank services context, developing new skills to solve work-related problems (e.g., meeting the deposit collection target through personal contact, innovative ways of interacting and convincing customers, etc.) and addressing these issues in 
a fearless and psychologically safe environment are crucial. Hence, employees' feeling of psychological safety is of utmost importance.

Employees become engaged at work based on the job resources they receive from their organisation (Saks, 2006). The term 'job resources' refers to those physical, psychological, social or organisational aspects of the job that: (i) reduce job demands and the associated physiological and psychological costs; (ii) are functional in achieving work goals; or (iii) stimulate personal growth, learning and development (Schaufeli and Bakker, 2004). As organisations commit resources by facilitating a favourable 'climate for initiative' and a favourable 'climate for psychological safety', the effects of these two key components of organisational climate on EE are supported by the job demands-resources (JD-R) model (Bakker and Demerouti, 2007; Demerouti et al., 2001b). The JD-R model asserts that internal resources (e.g., the climate for initiative and climate for psychological safety) are what an organisation can provide to its employees in order to accomplish their work. Existing research has provided mixed evidence regarding the effects of job resources on employee engagement (EE). While some studies have shown the positive impact of job resources on EE (e.g., Bakker and Demerouti, 2008; Bakker and Leiter, 2010; Halbesleben, 2010), others have mentioned that job resources may not always lead to work engagement. For example, Saks (2006) found no impact of supervisor support, rewards and recognition on job engagement. Christian et al. (2011) also found that autonomy and feedback had no impact on employee work engagement. In the context of financial services, the current study argues that enabling favourable climates for initiative and psychological safety is a precursor for $\mathrm{EE}$ as it leads to greater interdependence and interaction between employees and customers (Auh et al., 2007). In the case of financial services in emerging economies, entrepreneurial (Reynoso et al., 2015) and interpersonal (Malhotra et al., 2005; Sharma et al., 2012) initiatives play a vital role in a firm's success. Hence, their employees need to take initiative and go beyond their usual job responsibilities when interacting with customers due to the complex nature of financial services 
and the scope for a significant level of customisation (Auh et al., 2007). Hence, job resources such as favourable climates for initiative and psychological safety: (i) are instrumental in the achievement of employee work objectives; (ii) motivate employees to be engaged at work; (iii) are helpful in lessening the strain of the job's demands; and (iv) stimulate the personal growth and development of employees (Demerouti et al., 2001b). Therefore, it is hypothesised that:

\section{H1: The climate for initiative positively affects employee engagement.}

\section{H2: The climate for psychological safety positively affects employee engagement.}

\section{Customer Engagement}

Managing customer engagement (CE) has become a strategic priority for firms in building and sustaining long-term customer-firm relationships (Roy et al., 2018a). Customer engagement (CE) is a psychological state that occurs by virtue of interactive, co-creative customer experiences with a focal agent/object (e.g., a brand or firm) in focal service relationships (Brodie et al., 2011). It creates a deeper and meaningful connection between the company and the customer, with this connection enduring over time. In the extant literature, CE has been largely conceptualised as a multidimensional concept. For example, Vivek et al. (2014) argued for a three-dimensional conceptualisation of the construct, consisting of conscious attention, enthused participation and social connection. Hollebeek et al. (2014) mentioned that CE comprises three dimensions, namely, cognitive processing, affection and activation. Dessart et al. (2015) identified three key engagement dimensions, that is, cognition, affect and behaviours, for customer brand engagement in the online context. Similarly, Marino and Presti (2018) considered the three dimensions of $\mathrm{CE}$ as being conscious attention, enthused participation and social connection.

In the current study, $\mathrm{CE}$ is conceptualised as a psychological state that occurs due to interactive and co-creative customer experiences with a brand or firm through different channels, including online and offline. Based on Hollebeek (2011) and Hollebeek et al. (2014), 
a holistic view of $\mathrm{CE}$ is taken in the current study, which argues that the concept consists of numerous customer-firm interactions. These interactions encompass customers' entire purchase journey, ranging from their conscious attention toward the brand or firm through to their cognitive engagement, affective engagement and enthused participation with the firm's offerings, as well as other relevant activities across numerous offline and online channels. Therefore, four dimensions of $\mathrm{CE}$ are considered, namely, conscious attention, cognitive engagement, affective engagement and enthused participation. Conscious attention is the degree of interest that the customer has or wishes to have in interacting with the firm and its activities (Vivek et al., 2014). Cognitive engagement captures the participation of the customer both within and outside exchange situations between the firm and that customer (Vivek et al., 2012). The cognitive aspects of customer engagement enable customers to think about the firm and its different activities, thus stimulating the customer's interest in learning more about the firm. Affective engagement refers to a customer's degree of positive affect towards the firm or to the brand-related affect in a particular customer-firm interaction (Hollebeek et al., 2014). It incorporates the feelings of potential or current customers towards the firm and its activities across different channels (Vivek et al., 2012). On the other hand, enthused participation is defined as the degree to which the customer is involved in producing or delivering the service (Dabholkar, 1990). It enables an interactive situation for the customer that fulfils the common interest of both the firm and that customer (Vivek et al., 2012).

Existing research focuses on several factors that influence CE (see Appendix, Table B) such as customer involvement (Harrigan et al., 2017); product experience (Harmeling et al., 2017); customer trust and value in use (Roy et al., 2018a); perceived quality; service convenience; and fairness (Roy et al., 2018b). However, as is evident in Table B, research that focuses on the role of $\mathrm{EE}$ in $\mathrm{CE}$ is relatively sparse. The effects of $\mathrm{EE}$ on $\mathrm{CE}$ can be explained by emotional contagion theory (Hatfield et al., 1994) which focuses on how emotion is transmitted among individuals in social interaction. This theory suggests that emotions 
displayed by an individual (i.e., an employee) produce a corresponding change in the emotional state of the observer (i.e., the customer), and that this transmission of emotion may occur both at subconscious and conscious levels (Barsade, 2002; Hennig-Thurau et al., 2006). Emotional contagion occurs at the subconscious level when individuals automatically mimic and synchronise facial expressions and vocalisations and, consequently, converge emotionally (Hatfield et al., 1994). Conscious emotional contagion theory argues that individuals compare their mood with another person's mood and adopt the sender's emotive level when that appears appropriate (Barsade, 2002). Conscious emotional contagion is determined more by the authenticity with which emotions are displayed (e.g., genuineness of the employee's efforts displayed during interactions with the customer) than by the extent to which the sender displays emotions during an interaction (Hennig-Thurau et al., 2006). With regard to employeecustomer interaction, the current study argues that customers experience conscious emotional contagion when they find sincerity in the employee's efforts and emotions in terms of the employee's energy (i.e., vigour), dedication and absorption which is positively reflected in customers' emotion, attracting a favourable response. Thus, EE is expected to influence CE when emotion displayed by employees (derived from their genuine efforts) creates corresponding changes in customers' emotions and responses. The emotion contagion effect does not take place only within a single dyad of employee and customer; instead, it can span across to other employees who work together. As engagement is a psychological concept that can be shared by employees in the workplace (Bakker et al., 2005), employees working in a group are likely to interact with each other and thus have more possibilities of being involved in the psychological contagion process (Salanova et al., 2005). This process therefore involves employees in the workplace and the corresponding customers served by these employees as they interact with each other in an organisational setting.

In the context of financial services, $\mathrm{CE}$ with the service provider is more salient due to the nature of the service, which is characterised by high credence qualities, high degrees of 
customer contact and customisation, and high interdependence between customers and service providers to create favourable outcomes (Auh et al., 2007; Chan et al., 2010) for both customers and employees. Employees of financial services firms are required to be engaged in their work in order to engender a favourable response when serving customers. Prior research has provided evidence that emotions displayed by retail banking employees positively influence customer affect and customer evaluations of the quality of services received (Pugh, 2001). This is even more applicable in the emerging economy context due to the existence of a high level of interpersonal relationships between service employees and customers (Sharma et al., 2012). When employees are highly engaged with their work and share common perceptions about the quality of the service in their unit, it is expected that they will perform well with customers who will eventually feel engaged with employees and thus will report favourably on employee performance (Salanova et al., 2005). Therefore, in line with emotional contagion theory (Hatfield et al., 1994), the current study hypothesises that emotions displayed by an employee produce a corresponding change in the emotional state of the customer:

\section{H3: Employee engagement positively affects customer engagement.}

\section{Consequences of Customer Engagement}

As previously mentioned, emotions experienced by customers when interacting with employees influence their engagement which results in a positive impact on their purchase behaviour (Blasco-Arcas et al., 2016). Engagement empowers customers to involve themselves with a firm either positively or negatively in co-creation, social influence and referrals (Hoyer et al., 2010; Libai et al., 2010). Existing research (see Appendix, Table B) has reported various consequences of CE, such as competitive advantage (Kumar and Pansari, 2016); loyalty intention (Dwivedi, 2015); purchase intention (Gopalakrishna et al., 2017); and firm performance, including revenue benefits and cost savings (Harmeling et al., 2017). Customer engagement (CE) researchers have focused on behavioural manifestations (Bijmolt et al., 2010; Van Doorn et al., 2010; Verhoef et al., 2010) and the attitudinal aspect towards the firm or brand without the 
customer necessarily purchasing the product or service or planning to purchase it later. Customer engagement $(\mathrm{CE})$ is conceptualised based on interactions relating to a firm's or a brand's events and activities that involve the customer even though these are not directly related to the customer's search, alternative evaluation and decision-making process regarding the firm or brand (Vivek et al., 2012). Based on the above, the current study argues that CE influences customers' psychological state of mind as well as their behavioural intention. As commitment reflects an individual's positive attitude towards an object (Beatty and Kahle, 1988), an outcome of CE can be commitment to the firm or brand. Hence, relationship commitment and switching intention are considered as the two key outcomes of customer engagement (CE).

Commitment is the psychological attachment that a customer has towards a store and/or brand (Evanschitzky et al., 2006). Relationship commitment refers to an enduring desire to maintain a valued relationship with a firm or brand (Moorman et al., 1992; Rabbanee et al., 2012). Some customers are more likely than others to engage in these relationships. This means that the extent of relationship commitment may vary across customers (De Wulf et al., 2001). Hence, this research considers relationship commitment to be customers' belief that an ongoing relationship with their preferred firm or brand is important to them and that maintaining the relationship warrants their maximum efforts (Rabbanee et al., 2012). Customers receive numerous benefits by being engaged with the firm, its employees and its different activities. This affects the relationships that customers have with the firm or brand (Hollebeek, 2012). Positive interactive relationships between employees and customers are thought to increase customer loyalty (Berry and Parasuraman, 1991). An engaged customer's positive experience with the firm or brand is likely to increase his/her perception of the derived benefits (Vargo and Lusch, 2004; Vivek et al., 2014). Considering that relationship commitment is related more to the psychological attachments that customers have to a brand or firm (Thomson et al., 2005; Rabbanee et al., 2012), this commitment is likely to be influenced by customers' perceptions about the firm and its employees. The current study argues that, as commitment reflects an 
individual's positive attitude towards an object (Beatty and Kahle, 1988), being committed towards the firm or brand is the first-hand outcome of customer engagement (CE). This is also applicable in a financial services context as the more customers are engaged with the service provider, the better attitude they have towards the firm and the stronger is their commitment. Therefore, this study hypothesises that:

\section{H4: Customer engagement positively affects customer relationship commitment.}

Employee and customer interactions contribute to better perceptions in favour of a firm (Sirianni et al., 2013) which affect CE through repeat customer purchase (Kumar and Pansari, 2016), that is, by reducing the likelihood of switching. A sound employee-customer relationship within a bank reflects a high level of interaction (Chakravarty et al., 2004) which means engagement between the two parties and a lower tendency to switch from one bank to another. This relationship between employees and customers is considered to be the strongest barrier to customers' switching intention (Farah, 2017) in any services firm, including a financial services firm. However, as shown in Appendix, Table B, no research to date has examined the effects of CE on customers' switching intention. One study in a retail bank found that customers perceived a low (high) switching intention when experiencing a high (low) level of service response from bank employees (Levesque and McDougall, 1996). As customers who are more engaged perceive a higher level of importance in staying with their existing services firm (Bloemer and De Ruyter, 1999; Reinartz and Kumar, 2003), they psychologically lock themselves into staying with the firm and have a reduced level of switching intention (Dick and Basu, 1994). Therefore, it is hypothesised that:

\section{H5: Customer engagement negatively affects customer switching intention.}

These hypothesised relationships are depicted in the conceptual framework shown in Figure 1.

Insert Figure 1 about here 


\section{Method}

\section{Research Context}

The hypotheses shown in Figure 1 were tested in the context of banking services in Bangladesh. Bangladesh is an emerging economy in South Asia that, in 2015, achieved lower middleincome country status. In 2018, it fulfilled all three eligibility criteria for graduation from the United Nations (UN)'s Least-Developed Countries (LDCs) list (World Bank, 2017). With the move to becoming a middle-income country, Bangladesh is undergoing substantial economic activities in which the role of financial services, and especially the role of commercial banks, is crucial for enabling the channelisation of funds (Uddin and Suzuki, 2014) and sufficient investment resources (Mujeri and Younus, 2009). As of 2016, 57 commercial banks operated in Bangladesh with a total of 9,720 bank branches across the country (Bangladesh Bank, 2017). The deregulation of the banking sector enabled open competition, higher operational efficiency and better customer service than occurred prior to deregulation (Chowdhury and Raihan, 2000). This competitive situation in the banking industry also allows customers to enjoy greater bargaining power and to demand better customer service, as they are offered ample opportunities to switch from one bank to another. The commitment of the bank and the compassion of bank employees towards customers are found at the top of the list of bank selection criteria in Bangladesh (Andaleeb et al., 2016; Iqbal et al., 2018). This shows that, as with the banking services of other emerging economies (Malhotra et al., 2005), the predominant feature of the banking services firms of Bangladesh is a high level of human interaction and personal contact between employees and customers.

\section{Data Collection}

The data were collected through self-administered structured surveys conducted in Bangladesh among service employees and customers of 69 branches of 31 commercial banks (at least two bank branches from each bank) using two separate survey instruments—one for employees and the other for customers. The study targeted and approached employees who dealt with 
customers for their banking needs, with these employees selected after being approached through a network acquaintance (Colgate et al., 2007). The surveys aimed to select more than two employees and two customers (who had been served by these two employees) from each bank branch. Employees were asked to participate in the survey at a time mutually convenient to the respective employee and one of the authors involved in the data collection process. A total of 171 employees were approached, with 156 employees (about 91\% response rate) participating in the study. Customers were approached to participate in the survey after being served by the respective employees. Customer respondents who agreed to participate were then asked to complete the survey questionnaire at a waiting area desk separate to the corresponding employee's desk. A total of 411 customers were approached, with 316 customers (about 77\% response rate) completing the survey questionnaire. To ensure the confidentiality and anonymity of their responses, employees and customers were both provided with an envelope in which to insert their completed survey questionnaire, with the envelope then sealed.

\section{Measures}

The measures of the constructs were adapted from the existing literature after due contextualisation. The measures of the climate for initiative and the climate for psychological safety were adapted from Frese et al. (1997) and Edmondson (1999), respectively, both of which were used by Baer and Frese (2003). As indicated earlier in the literature review section, EE at work was conceptualised as consisting of three key dimensions: vigour, dedication and absorption. These dimensions were measured using scale items adapted from Schaufeli et al. (2002), with high scores for vigour, dedication and absorption indicative of high engagement at work. The dimensions of CE, namely, conscious attention, cognitive engagement, affective engagement and enthused participation were measured using scale items adapted from Vivek et al. (2014) and Hollebeek et al. (2014). The scale items for measuring relationship commitment were adopted from Morgan and Hunt (1994). Switching intention was measured 
using three items adopted from Bansal et al. (2005). All items were measured using a sevenpoint Likert scale ranging from 1 'strongly disagree' to 7 'strongly agree'.

\section{Data Analysis and Results}

A dyadic data set was created by matching customer data with the corresponding employee data collected from each bank branch. Following Salanova et al. (2005), the current study aggregated both employee and customer data under the dyadic data set and used structural equation modelling (SEM) (AMOS version 22.0) for analysis. Using both employee and customer data simultaneously in a matched data set to test the study's hypotheses helped to avoid problems that could arise from the common-variance method. Both exploratory factor analysis (EFA) and confirmatory factor analysis (CFA) were run to test the reliability and validity of the constructs and their dimensions. The EFA results revealed that the items loaded highly on the respective construct. The convergent validity of the constructs was tested by checking the factor loading of all items, with these found to load significantly (at the 0.01 level) onto the expected latent construct (Hair et al., 2010). The descriptive statistics and factor loadings of the scale items corresponding to the constructs are shown in Table 1. The lowest value of construct reliability (CR) was 0.80 for 'climate for psychological safety', which suggested adequate internal consistency of the study's scale items.

The correlation values (see Table 2) between the constructs and their dimensions, that is: 'climate for initiative'; 'climate for psychological safety'; dimensions of 'employee engagement (EE)' (vigour, dedication and absorption); dimensions of 'customer engagement (CE)' (conscious attention, cognitive engagement, affective engagement and enthused participation); 'relationship commitment'; and 'switching intention' were within the acceptable limit, thus supporting the discriminant validity of the constructs (Kline, 2005). The minimum average variance extracted (AVE) was found to be 0.504 for 'climate for psychological safety', which matched the minimum cut-off point (Hair et al., 2010), thus supporting the discriminant 
validity of the constructs used in the model (Bagozzi and Yi, 1988). The goodness-of-fit measures for the measurement model showed an acceptable fit with the data $(\chi 2=752.53 ; d f=$ 216; $\chi 2 / d f=3.48 ;$ RMSEA $=0.08 ; \mathrm{CFI}=0.92 ; \mathrm{NFI}=0.90 ; \mathrm{TLI}=0.90)$, suggesting that the constructs were different from each other.

Insert Table 1 about here

Insert Table 2 about here

The average age of employees was approximately 28 years. The average duration of being an employee of the bank was 5.28 years. The average age of customers was about 37 years, while the average duration of being a customer of the respective bank branch was 4.66 years. As shown in Figure 1, the path relationships were tested by running the structural model, with the fit indices found to be within the acceptable limit $(\chi 2=698.38 ; d f=225 ; \chi 2 / d f=$ 3.10; $\mathrm{RMSEA}=0.08 ; \mathrm{CFI}=0.93 ; \mathrm{NFI}=0.90 ; \mathrm{TLI}=0.91)$. The structural path relationships are shown in Table 3.

Insert Table 3 about here

As shown in Table 3, all the hypothesised relationships were significant. The 'climate for initiative' $(\mathrm{H} 1: \beta=0.22 ; t=4.05)$ and the 'climate for psychological safety' $(\mathrm{H} 2: \beta=0.46$; $t=5.28)$ significantly influenced 'employee engagement (EE)', explaining $35 \%$ of its variance $\left(r^{2}=0.35\right)$. 'Employee engagement $(\mathrm{EE})$ ' positively influenced 'customer engagement $(\mathrm{CE})$ ' (H3: $\beta=0.84 ; t=14.34)$ and explained $72 \%$ of its variance $\left(\mathrm{r}^{2}=0.72\right)$. 'Customer engagement (CE)' positively influenced 'relationship commitment' (H4: $\beta=0.85 ; t=16.96)$ and negatively influenced 'switching intention' (H5: $\beta=-0.78 ; t=-15.14$ ), thus explaining $73 \%$ and $61 \%$ of variance, respectively. 


\section{Discussion}

The current study focuses on managing the engagement of both internal stakeholders (employees) and external stakeholders (customers) of services firms. It explores: (a) the drivers of EE; (b) the effects of EE on CE; and (c) the consequences of CE in terms of relationship commitment and switching intention in the context of a banking services of an emerging economy, in this case, Bangladesh. Understanding the above relationships in the context of financial services is important as the industry is characterised by high customer switching, low EE, high employee turnover and absenteeism (LMA, 2018). Moreover, disengaged account executives of a financial institution have been found to bring in $28 \%$ less revenue than engaged executives (Seijts and Crim, 2006). Drawing on the job demands-resources (JD-R) model (Demerouti et al., 2001b) and emotional contagion theory (Hatfield et al., 1994), this study examines the effects of organisational climates for initiative and psychological safety on EE and through to $\mathrm{CE}$, customer commitment and switching intention. The findings reveal that these organisational climates positively influence employee engagement (EE). These findings are in line with Fung et al. (2017) who found that the organisational service climate has a stronger effect on internal service quality delivered by employees with higher levels of interdependence (e.g., employees of emerging economies) compared to those with higher independence (e.g., employees of developed countries). Furthermore, EE significantly influences $\mathrm{CE}$ and $\mathrm{CE}$ is found to have a positive impact on customers' relationship commitment and a deterring effect on customers' switching intention. Thus, the study's findings not only reinforce the link between job resources and engagement (Qi et al., 2018) but go beyond by linking EE with CE, customer commitment and switching intention. The study's finding that EE significantly influences $\mathrm{CE}$ is in line with the finding of Kumar and Pansari (2016), although the current study conceptualised and measured EE and CE from a psychological perspective. 


\section{Implications}

The theoretical contributions of the study are threefold. Firstly, the study contributes to the existing engagement literature by offering novel insights about the drivers and consequences of engagement. To be specific, the study presents empirical evidence in support of two new drivers of EE, namely, the climate for initiative and the climate for psychological safety. As organisational resources, these drivers emphasise the resource-engagement link. Thus, the study extends the job demands-resources (JD-R) model by presenting evidence that organisational resources, such as the climate for initiative and the climate for psychological safety, influence employee engagement (EE). On the consequence side, the study identifies two new outcome variables for $\mathrm{CE}$, namely, relationship commitment and switching intention. Secondly, the study extends emotional contagion theory by showing its application in explaining the EE-CE relationship, and exploring this relationship from the psychological perspective. It also provides useful insights into the psychological mechanism underlying the EE-CE link by emphasising the conscious transmission of emotion between employees and customers. Thirdly, the study's findings offer a better understanding of managing engagement in banking services of an emerging economy like Bangladesh, by offering a model that reflects the chain of relationships stemming from organisational climate through to EE, CE and customer-based outcomes. The current study thus addresses the recent call from Kumar and Pansari (2016) for further research on engagement. These researchers tested their model in several US industries including engineering, technology, electronics, furniture manufacturers, consumer products manufacturers, mass media, airlines and retail outlets, and urged that more research on engagement be conducted in different industry and country contexts.

In addition to its theoretical contributions, the study has significant practical implications for service managers. The role of service employees is recognised as critical in achieving customer-oriented goals (Menguc et al., 2017). The current study underscores the need to facilitate a favourable organisational climate, one which emphasises the taking of 
personal initiative and feeling psychologically safe at work to ensure employees' work engagement. For this purpose, service managers need to ensure an initiative-enhancing human resource management (HRM) system within the organisation which is likely to positively affect the department-level climate for initiative (Hong et al., 2016). An HRM system that enhances initiative involves selecting employees with dispositional proactivity and capabilities (Schneider et al., 2000), and offering training to improve employee self-efficacy (Axtell and Parker, 2003) and to enhance their current proactivity (Fay and Sonnentag, 2010). Such a system requires top management support (Baer and Frese, 2003) and job autonomy (Parker et al., 2006), and having in place an effective performance appraisal system (Schuler and Jackson, 1987). Job autonomy enhances the control of an employee over the task, thus helping him/her to effectively discharge his/her job responsibilities. Effective performance appraisal, due to the rewards associated with performance, encourages employees to repeat the initiatives they have undertaken. To ensure the climate for psychological safety, employees will feel safe at work if the climate is open (Carmeli et al., 2009), supportive (Edmondson, 2004) and trustworthy (Kahn, 1990). Having an open and supportive environment in a firm depends on the style of management, as managers are responsible for translating the system demands to employees and for reinforcing employee behaviour (Louis, 1986). The perception of a trustworthy environment is fostered when employees experience supervisory support and harmonious coworker relationships (McAllister, 1995) which help them to develop new skills and ways of solving work-related problems (Deci and Ryan, 1987; May et al., 2004). Therefore, firms should invest in leadership training and select supervisors with an appropriate leadership style before initiating the implementation of innovations, that is, employee initiatives (Michaelis et al., 2010).

Services firms can draw upon the current study's findings to facilitate the desired work environment (i.e., the organisational climate) based on employees' perceptions of their employers' performance in providing job resources. A balance should be established between 
employees' perceptions and the services firm's performance in providing job resources, with key factors worth considering including competitors' benchmarks, firm size, number of employees, location of the firm, etc. (Qi et al., 2018). Managers can also invest resources to enhance the level of vigour, dedication and absorption of service employees as part of the EE strategy, as suggested in this study's findings. As engaged employees may also act as a potential switching barrier (Colgate et al., 2007), if managers ignore EE, this may lead to missing an effective way of differentiating their offerings in addition to their core product or service.

The study's findings also emphasise that managers must pay attention to employees' psychological motivation to ensure the quality and competitiveness of their firms' services. As employees share collective feelings in the workplace (Salanova et al., 2005), managers need to adopt appropriate steps to proactively engage each employee to avoid the contagion effect of one disengaged employee affecting others. This is of particular importance in an emerging economy like Bangladesh where the contagion effect of a disengaged employee could cause severe cumulative damage due to the collective nature of the employees and customers. Further, the bank managers of such economies face other challenges, such as deciding appropriate strategies for employee motivation and rewarding, acquiring new customers, and ensuring proper customer understanding of the banking products (e.g., deposits, investments, loan amortisation, etc.). Enabling the climates for initiative and psychological safety can help the bank managers address these challenges and thus engage employees at work. Moreover, in line with this study's finding that CE influences customers' commitment and switching intention, managers should ensure that customers are adequately engaged with their brand, products and services in order to retain customers and obtain their commitment.

\section{Limitations}

The current study has a few limitations. Firstly, the model proposed in this study considers two components of organisational climate (the climate for initiative and the climate for 
psychological safety) as the key EE antecedents. Future research may consider focusing on other relevant factors, such as innovative culture (Menon and Varadarajan, 1992; Ramaseshan et al., 2013), or supervisory support and feedback (Menguc et al., 2013) that may influence employee engagement (EE). Secondly, the current study has presented empirical evidence in support of the effect of EE on CE, customer commitment and switching intention. Future research may consider actual customer behaviour, such as repeat purchase, as the key outcome variable in the model. Thirdly, the study's proposed model does not include any feedback loop from customer attitude and intention to organisational resources. Hence, future research is warranted to examine these continuous path relationships including the feedback loop from the customer-based outcome variable to drivers of employee engagement (EE). Fourthly, this study is based on a cross-sectional survey design; hence, the reciprocal relationships between employees and customers cannot be fully interpreted causally, which is something that future researchers may consider exploring. Finally, this study focuses on the banking services sector of an emerging economy. The model could be replicated in a different industry context as well as in a developed country context. 


\section{References}

Amiti, M. and Wei, S. J. (2009), "Service offshoring and productivity: Evidence from the US", World Economy, Vol. 32 No. 2, pp. 203-220.

Anaza, A. N. and Rutherford, B. (2012), "How organizational and employee-customer identification, and customer orientation affect job engagement", Journal of Service Management, Vol. 23 No. 5, pp. 616-639.

Andaleeb, S. S., Rashid, M., and Rahman, Q. A. (2016), “A model of customer-centric banking practices for corporate clients in Bangladesh," International Journal of Bank Marketing, Vol 34 No. 4, pp. 458-475.

Auh, S., Bell, S. J., McLeod, C. S. and Shih, E. (2007), "Co-production and customer loyalty in financial services", Journal of Retailing, Vol. 83 No. 3, pp. 359-370.

Auh, S., Menguc, B., Spyropoulou, S. and Wang, F. (2016), "Service employee burnout and engagement: the moderating role of power distance orientation", Journal of the Academy of Marketing Science, Vol. 44 No. 6, pp.726-745.

Axtell, C. M. and Parker, S. K. (2003), "Promoting role breadth self-efficacy through involvement, work redesign and training”, Human Relations, Vol. 56, pp. 113-131.

Baer, M. and Frese, M. (2003), "Innovation is not enough: Climates for initiative and psychological safety, process innovations, and firm performance", Journal of Organizational Behavior, Vol. 24 No. 1, pp. 45-68.

Bagozzi, R. P. and Yi, Y. (1988), "On the evaluation of structural equation models", Journal of the Academy of Marketing Science, Vol. 16 No. 1, pp. 74-94.

Bailey, C., Madden, A., Alfes, K. and Fletcher, L. (2017), “The meaning, antecedents and outcomes of employee engagement: A narrative synthesis", International Journal of Management Reviews, Vol. 19 No. 1, pp. 31-53.

Bakker, A. B. and Demerouti, E. (2007), “The job demands-resources model: State of the art”, Journal of Managerial Psychology, Vol. 22 No. 3, pp. 309-328.

Bakker, A. B. and Demerouti, E. (2008), "Towards a model of work engagement", Career Development International, Vol. 13 No. 3, pp. 209-223. 
Bakker, A.B. and Demerouti, E. (2014), "Job demands-resources theory", in Chen, P.Y. and Cooper, C.L. (Eds), Wellbeing: A Complete Reference Guide, Volume III, Work and Wellbeing, Wiley Blackwell, New York, NY, pp. 37-64.

Bakker, A. B., Demerouti, E. and Schaufeli, W. B. (2005), "The crossover of burnout and work engagement among working couples”, Human Relations, Vol. 58 No. 5, pp. 661-689.

Bakker, A. B. and Leiter, M. P. (2010), "Work engagement: A handbook of essential theory and research", In A. B. Bakker, \& M. P. Leiter (Eds.), Work Engagement: A Handbook of Essential Theory and Research. New York: Psychology Press.

Bangladesh Bank. (2017). Annual Report, 2016 - 2017. Dhaka: Bangladesh Bank.

Bansal, H. S., Taylor, S. F. and James, S. Y. (2005), "Migrating" to new service providers: Toward a unifying framework of consumers' switching behaviors", Journal of the Academy of Marketing Science, Vol. 33 No. 1, pp. 96-115.

Barrick, M. R., Thurgood, G. R., Smith, T. A. and Courtright, S. H. (2015), "Collective organizational engagement: Linking motivational antecedents, strategic implementation, and firm performance", Academy of Management Journal, Vol. 58 No. 1, pp. 111-135.

Barsade, S. G. (2002), “The Ripple Effect: Emotional Contagion and Its Influence on Group Behavior," Administrative Science Quarterly, 47 (December), pp. 644-75.

Beatty, S. E. and Kahle, L. R. (1988), "Alternative hierarchies of the attitude-behavior relationship: The impact of brand commitment and habit", Journal of the Academy of Marketing Science, Vol. 16 No. 2, pp. 1-10.

Beckers, S. F., Van Doorn, J. and Verhoef, P. C. (2018), “Good, better, engaged? The effect of company-initiated customer engagement behavior on shareholder value", Journal of the Academy of Marketing Science, Vol. 46, pp. 366-383.

Beek, I. V., Hu, Q., Schaufeli, W. B., Taris, T. W. and Schreurs, B. H. (2012), "For fun, love, or money: What drives workaholic, engaged, and burned-out employees at work?", Applied Psychology, Vol. 61 No. 1, pp. 30-55.

Berry, L. L. and Parasuraman, A. (1991), Marketing services: Competing through Quality, New York: Free Press.

Bijmolt, T. H., Leeflang, P. S., Block, F., Eisenbeiss, M., Hardie, B. G., Lemmens, A. and Saffert, P. (2010), “Analytics for customer engagement”, Journal of Service Research, Vol. 13 No. 3, pp. 341-356. 
Blasco-Arcas, L., Hernandez-Ortega, B. I., Jimenez-Martinez, J. (2016), "Engagement platforms: The role of emotions in fostering customer engagement and brand image in interactive media", Journal of Service Theory and Practice, Vol. 26 Issue: 5, pp.559-589.

Bloemer, J. and De Ruyter, K. (1999), "Customer loyalty in high and low involvement service settings: the moderating impact of positive emotions", Journal of Marketing Management, Vol. 15 No. 4, pp. 315-330.

Boardman, D., Raciti, M. M. and Lawley, M. (2018) "Outperformed: how the envy reflex influences status seeking service consumers' engagement", Journal of Service Theory and Practice, Vol. 28 No. 6, pp.752-773.

Bock, G. W., Lee, J. N., Zmud, R. W. and Kim, Y. G. (2005), "Behavioral intention formation in knowledge sharing: Examining the roles of extrinsic motivators, social-psychological forces, and organizational climate", MIS Quarterly, Vol. 29 No. 1, pp. 87-111.

Boudrias, J.-S., Brunet, L., Morin, A. J., Savoie, A., Plunier, P. and Cacciatore, G. (2010), "Empowering employees: The moderating role of perceived organizational climate and justice”, Canadian Journal of Behavioural Science, Vol. 42 No. 4, pp. 201-211.

Breevaart, K., Bakker, A. B., Demerouti, E. and Derks, D. (2016), "Who takes the lead? A multi-source diary study on leadership, work engagement, and job performance" Journal of Organizational Behavior, Vol. 37 No. 3, pp. 309-325.

Brodie, R. J., Hollebeek, L. D., Jurić, B. and Ilić, A. (2011), "Customer engagement: Conceptual domain, fundamental propositions, and implications for research", Journal of Service Research, Vol. 14 No. 3, pp. 252-271.

Carmeli, A., Brueller, D. and Dutton, J. E. (2009), "Learning behaviours in the workplace: The role of high-quality interpersonal relationships and psychological safety", Systems Research and Behavioral Science, Vol. 26, pp. 81-98.

Catteeuw, F., Flynn, E. and Vonderhorst, J. (2007), "Employee Engagement: Boosting Productivity in Turbulent Times", Organization Development Journal, Vol. 25 No. 2, pp. 151-157.

Chakravarty, S., Feinberg, R. and Rhee, E.-Y. (2004), "Relationships and individuals' bank switching behavior", Journal of Economic Psychology, Vol. 25 No. 4, pp. 507-527. 
Chan, K. W., Yim, C. K. and Lam, S. S. (2010), "Is customer participation in value creation a double-edged sword? Evidence from professional financial services across cultures”, Journal of Marketing, Vol. 74 No. 3, pp. 48-64.

Chandler, J. D., and Lusch, R. F. (2015), "Service systems: A broadened framework and research agenda on value propositions, engagement, and service experience", Journal of Service Research, Vol. 18 No. 1, pp. 6-22.

Chowdhury, T. A. and Raihan, A. (2000), "Implications of Financial Sector Reforms", Dhaka: Structural Adjustment Participatory Review Initiative (SAPRI).

Christian, M. S., Garza, A. S. and Slaughter, J. E. (2011), "Work engagement: A quantitative review and test of its relations with task and contextual performance", Personnel Psychology, Vol. 64 No. 1, pp. 89-136.

Clark, M. (2002), “The relationship between employees' perceptions of organizational climate and customer retention rates in a major retail bank", Journal of Strategic Marketing, Vol. 10 No. 2, pp. 93-113.

Colgate, M., Tong, V. T. U., Lee, C. K. C. and Farley, J. U. (2007), "Back from the brink: Why customers stay”, Journal of Service Research, Vol. 9 No. 3, pp. 211-228.

Crawford, E. R., LePine, J. A. and Rich, B. L. (2010), "Linking job demands and resources to employee engagement and burnout: a theoretical extension and meta-analytic test", Journal of Applied Psychology, Vol. 95 No. 5, pp. 834-848.

Dabholkar, P. A. (1990), "How to Improve Perceived Service Quality by Improving Customer Participation," in Development in Marketing Science, B.J. Dunlap, ed., Cullowhee, NC: Academy of Marketing Science, 483-487.

De Wulf, K., Odekerken-Schröder, G., and Iacobucci, D. (2001), "Investments in consumer relationships: A cross-country and cross-industry exploration", Journal of marketing, Vol. 65 No. 4, pp. 33-50.

Deci, E. L. and Ryan, R. M. (1987), "The support of autonomy and the control of behavior", Journal of Personality and Social Psychology, Vol. 53 No.6, pp. 1024-1037.

Demerouti, E., Bakker, A. B., De Jonge, J., Janssen, P. P. and Schaufeli, W. B. (2001a), "Burnout and engagement at work as a function of demands and control", Scandinavian Journal of Work, Environment and Health, Vol. 27 No. 4, pp. 279-286. 
Demerouti, E., Bakker, A. B., Nachreiner, F. and Schaufeli, W. B. (2001b), "The job demandsresources model of burnout", Journal of Applied Psychology, Vol. 86 No. 3, pp. 499-512.

Dessart, L., Veloutsou, C. and Morgan-Thomas, A. (2015), "Consumer engagement in online brand communities: a social media perspective", Journal of Product and Brand Management, Vol. 24 No. 1, pp. 28-42.

Dick, A. S. and Basu, K. (1994), "Customer loyalty: toward an integrated conceptual framework", Journal of the Academy of Marketing Science, Vol. 22 No. 2, pp. 99-113.

Dollard, M. F. and Bakker, A. B. (2010), "Psychosocial safety climate as a precursor to conducive work environments, psychological health problems, and employee engagement", Journal of Occupational and Organizational Psychology, Vol. 83 No. 3, pp. 579-599.

Dwivedi, A. (2015), “A higher-order model of consumer brand engagement and its impact on loyalty intentions", Journal of Retailing and Consumer Services, Vol. 24, pp. 100-109.

Edmondson, A. (1996), "Learning from mistakes is easier said than done: Group and organizational influences on the detection and correction of human error," Journal of Applied Behavioral Science, Vol. 32, pp. 5-32.

Edmondson, A. (1999), "Psychological safety and learning behavior in work teams", Administrative Science Quarterly, Vol. 44 No. 2, pp. 350-383.

Edmondson, A. (2004), "Psychological Safety, Trust and Learning: A Group-level Lens. In R. Kramer, \& K. Cook (Eds.)", Trust and Distrust in Organizations: Dilemmas and Appraches, New York: Russell Sage Foundation, pp. 239-272.

Eldor, L. and Harpaz, I. (2016), “A process model of employee engagement: The learning climate and its relationship with extra-role performance behaviors", Journal of Organizational Behavior, Vol. 37 No. 2, pp. 213-235.

Evanschitzky, H., Iyer, G. R., Plassmann, H., Niessing, J. and Meffert, H. (2006), “The relative strength of affective commitment in securing loyalty in service relationships", Journal of Business Research, Vol. 59 No. 12, pp. 1207-1213.

Farah, M. F. (2017), “Consumers' switching motivations and intention in the case of bank mergers: A cross-cultural study", International Journal of Bank Marketing, Vol. 35 No. 2, pp. 254-274. 
Fay, D. and Sonnentag, S. (2010), “A look back to move ahead: New directions for research on proactive performance and other discretionary work behaviours", Applied Psychology, Vol. 59, pp. 1-20.

Frese, M., Brantjes, A. and Hoorn, R. (2002), "Psychological success factors of small scale businesses in Namibia: The roles of strategy process, entrepreneurial orientation and the environment", Journal of Developmental Entrepreneurship, Vol. 7 No. 3, pp. 259-282.

Frese, M. and Fay, D. (2001), "Personal initiative: An active performance concept for work in the 21st century", Research in Organizational Behavior, Vol. 23, pp. 133-187.

Frese, M., Fay, D., Hilburger, T., Leng, K. and Tag, A. (1997), “The conception of personal initiative: Operationalization, reliability and validity in two German samples", Journal of Occupational and Organizational Psychology, Vol. 70 No. 2, pp. 139-161.

Fung, C., Sharma, P., Wu, Z. and Su, Y. (2017), "Exploring service climate and employee performance in multicultural service settings," Journal of Services Marketing, Vol 31 No. 7, pp. 784-798.

Gallup, L. L. C. (2013), State of the American workplace: Employee engagement insights for US business leaders, Retrieved from Washington, DC: http://www. gallup.com.

Ghosh, P., Rai, A. and Sinha, A. (2014), “Organizational justice and employee engagement: Exploring the linkage in public sector banks in India", Personnel Review, Vol. 43 No. 4 , pp. 628-652.

Gibb, J. R. (1961), “Defensive communication”, Journal of Communication, Vol. 11 No. 3, pp. 141-148.

Gopalakrishna, S., Malthouse, E. C. and Lawrence, J. M. (2017), "Managing customer engagement at trade shows", Industrial Marketing Management.

Griffin, M. A., Neal, A., and Parker, S. K. (2007), “A new model of work role performance: Positive behavior in uncertain and interdependent contexts", Academy of management journal, Vol. 50 No. 2, pp. 327-347.

Gruman, J. A. and Saks, A. M. (2011), "Performance management and employee engagement", Human Resource Management Review, Vol. 21 No. 2, pp. 123-136.

Gupta, M., Ganguli, S. and Ponnam, A. (2015), "Factors Affecting Employee Engagement in India: A Study on Offshoring of Financial Services", The Qualitative Report, Vol 20, No 4, pp. 498-515. 
Gupta, S., Pansari, A. and Kumar, V. (2018), "Global Customer Engagement", Journal of International Marketing, Vol. 26 No. 1, pp. 4-29.

Hackman, J. R. and Oldham, G. R. (1976), "Motivation through the design of work: Test of a theory”, Organizational Behavior and Human Performance, Vol.16 No. 2, pp. 250279.

Hair, J. F., Black, W. C., Babin, B. J. and Anderson, R. E. (2010), Multivariate data analysis A global perspective (Seventh Ed.), Upper Saddle River, New Jersey: Pearson Education, Inc.

Halbesleben, J. R. (2010), “A meta-analysis of work engagement: Relationships with burnout, demands, resources and consequences”, In A. B. Bakker, \& M. P. Leiter (Eds.), Work Engagement: A Handbook of Essential Theory and Research, Vol. 8 No. 1, pp. 102117. New York: Psychology Press

Harmeling, C. M., Moffett, J. W., Arnold, M. J. and Carlson, B. D. (2017), “Toward a theory of customer engagement marketing", Journal of the Academy of Marketing Science, Vol. 45 No. 3, pp. 312-335.

Harrigan, P., Evers, U., Miles, M. and Daly, T. (2017), “Customer engagement with tourism social media brands", Tourism Management, Vol. 59, pp. 597-609.

Harrigan, P., Evers, U., Miles, M. and Daly, T. (2018), "Customer engagement and the relationship between involvement, engagement, self-brand connection and brand usage intent", Journal of Business Research, Vol. 88, pp. 388-396.

Harter, J. K., Schmidt, F. L. and Hayes, T. L. (2002), "Business-unit-level relationship between employee satisfaction, employee engagement, and business outcomes: a metaanalysis", Journal of Applied Psychology, Vol. 87 No. 2, pp. 268-279.

Hatfield, E., Cacioppo, J.T. and Rapson, R.L. (1994), Emotional contagion. New York: Cambridge University Press.

He, H., Chao, M. M. and Zhu, W. (2019), “Cause-related marketing and employee engagement: The roles of admiration, implicit morality beliefs, and moral identity", Journal of Business Research, Vol. 95, pp. 83-92.

Heinonen, K. (2018) "Positive and negative valence influencing consumer engagement", Journal of Service Theory and Practice, Vol. 28 No. 2, pp.147-169. 
Hennig-Thurau, T., Groth, M., Paul, M. and Gremler, D. D. (2006), "Are all smiles created equal? How emotional contagion and emotional labor affect service relationships," Journal of Marketing, Vol 70, No. 3, pp. 58-73.

Hofstede, G.H. (1991), Cultures and organizations: Software of the mind. London: McGrawHill.

Hofstede, G. H. (2001), Culture's consequences: Comparing values, behaviors, institutions, and organizations across nations. 2nd ed. Thousand Oaks, CA: Sage.

Hollebeek, L. D. (2011), “Demystifying customer brand engagement: Exploring the loyalty nexus", Journal of Marketing Management, Vol. 27 No. 7-8, pp. 785-807.

Hollebeek, L. (2012), Demystifying 'brand usage engagement' in social networking contexts: Conceptualisation, scale development and validation (Doctoral dissertation, ResearchSpace@Auckland).

Hollebeek, L. D., Glynn, M. S. and Brodie, R. J. (2014), “Consumer brand engagement in social media: Conceptualization, scale development and validation", Journal of Interactive Marketing, Vol. 28 No. 2, pp. 149-165.

Hollebeek, L. D., Srivastava, R. K. and Chen, T. (2019), "SD logic-informed customer engagement: integrative framework, revised fundamental propositions, and application to CRM", Journal of the Academy of Marketing Science, Vol. 47 No. 1, pp. 161-185.

Hong, Y., Liao, H., Raub, S. and Han, J. H. (2016), "What it takes to get proactive: An integrative multilevel model of teh antecedents of personal initiative", Journal of Applied Psychology, Vol. 101 No. 5, pp. 687-701.

Hoyer, W. D., Chandy, R., Dorotic, M., Krafft, M. and Singh, S. S. (2010), "Consumer cocreation in new product development", Journal of Service Research, Vol. 13 No. 3, pp. 283-296.

Iqbal, M., Nisha, N. and Rashid, M. (2018), "Bank selection criteria and satisfaction of retail customers of Islamic banks in Bangladesh," International Journal of Bank Marketing, Vol. 36 No. 5, pp. 931-946.

Jaakkola, E. and Alexander, M. (2014), "The role of customer engagement behavior in value co-creation: a service system perspective", Journal of Service Research, Vol. 17 No. 3 , pp. $247-261$. 
James, L. R., Joyce, W. F. and Slocum Jr, J. W. (1988), “Comment: Organizations do not cognize", Academy of Management Review, Vol. 13 No. 1, pp. 129-132.

Jourard, S. M. (1968), Disclosing man to himself, Princeton, NJ: D., Van Nostrand Co.

Kahn, W. A. (1990), "Psychological conditions of personal engagement and disengagement at work", Academy of Management Journal, Vol. 33 No. 4, pp. 672-724.

Kahn, W. A. (1992), “To be fully there: Psychological presence at work", Human Relations, Vol. 45 No. 4, pp. 321-349.

Karatepe, O. M., Yavas, U., Babakus, E. and Deitz, G. D. (2018), “The effects of organizational and personal resources on stress, engagement, and job outcomes", International Journal of Hospitality Management.

Kikuchi, T. and Van L. N. (2010), "A simple model of service offshoring with time zone differences", The North American Journal of Economics and Finance, Vol. 21 No. 3, pp. 217-227.

Kline, R. B. (2005), Principles and practice of structural equation modelling (2nd ed.), New York: The Guilford Press.

Kumar, V. (2013), Profitable customer engagement: concept, metrics and strategies, SAGE Publications, India.

Kumar, V. and Pansari, A. (2016), "Competitive advantage through engagement", Journal of Marketing Research, Vol. 53 No. 4, pp. 497-514.

Kumar, V., Rajan, B., Gupta, S., and Pozza, I.D. (2017), "Customer engagement in service”, Journal of the Academy of Marketing Science, Vol. 4, pp. 1-23.

Kwon, B., Farndale, E. and Park, J. G. (2016), "Employee voice and work engagement: Macro, meso, and micro-level drivers of convergence?" Human Resource Management Review, Vol. 26 No. 4, pp. 327-337.

Lazarus, R. S. (1995), "Psychological stress in the workplace", Occupational stress: $A$ handbook, 1, Taylor \& Francis, New York, pp. 3-14.

Lee, J. J. and Ok, C. M. (2015), "Drivers of work engagement: An examination of core selfevaluations and psychological climate among hotel employees", International Journal of Hospitality Management, Vol. 44, pp. 84-98.

Levesque, T. and McDougall, G. H. (1996), "Determinants of customer satisfaction in retail banking”, International Journal of Bank Marketing, Vol. 14 No. 7, pp. 12-20. 
Libai, B., Bolton, R., Bügel, M. S., De Ruyter, K., Götz, O., Risselada, H. and Stephen, A. T. (2010), "Customer-to-customer interactions: broadening the scope of word of mouth research", Journal of Service Research, Vol. 13 No. 3, pp. 267-282.

Liu, J., Cho, S. and Putra, E. D. (2017), "The moderating effect of self-efficacy and gender on work engagement for restaurant employees in the United States", International Journal of Contemporary Hospitality Management, Vol. 29 No. 1, pp. 624-642.

LMA (2018), "Employee Engagement in the Finance Industry”, May 10, Report found at https://news.levymarketingawards.com/blog/2018/05/employee-engagement-in-thefinance-industry.

Lockwood, N. R. (2007), “Leveraging employee engagement for competitive advantage”, SHRM Research Quarterly, Vol. 52 No. 3, pp. 1-12.

Louis, M. R. (1986), Putting executive action in context: An alternative view of power. In S. Srivastva, \& Associates (Eds.), Executive power (pp. 111-131). San Francisco: JosseyBass.

Lyu, Y., Zhu, H., Zhong, H. J. and Hu, L. (2016), “Abusive supervision and customer-oriented organizational citizenship behavior: The roles of hostile attribution bias and work engagement", International Journal of Hospitality Management, Vol. 53, pp. 69-80.

Malhotra, N. K., Ulgado, F. M., Agarwal, J., Shainesh, G. and Wu, L. (2005), "Dimensions of service quality in developed and developing economies: multi-country cross-cultural comparisons", International Marketing Review, Vol. 22 No. 3, pp. 256-278.

Marino, V. and Presti, L.L. (2018), "Engagement, satisfaction and customer behavior-based CRM performance: An empirical study of mobile instant messaging”, Journal of Service Theory and Practice, Vol. 28 No. 5, pp.682-707.

Maslowska, E., Malthouse, E. C. and Collinger, T. (2016). "The customer engagement ecosystem”, Journal of Marketing Management, Vol. 32 No. 5-6, pp. 469-501.

May, D. R., Gilson, R. L. and Harter, L. M. (2004), "The psychological conditions of meaningfulness, safety and availability and the engagement of the human spirit at work", Journal of Occupational and Organizational Psychology, Vol. 77 No. 1, pp. 11-37.

McAllister, D. J. (1995), “Affect and cognition based trust as foundations for interpersonal cooperation in organizations", Academy of Management Journal, Vol. 38, pp. 24-59. 
Menguc, B., Auh, S., Fisher, M. and Haddad, A. (2013), “To be engaged or not to be engaged: The antecedents and consequences of service employee engagement", Journal of Business Research, Vol. 66 No. 11, pp. 2163-2170.

Menguc, B., Auh, S., Yeniaras, V. and Katsikeas, C. S. (2017), "The role of climate: implications for service employee engagement and customer service performance", Journal of the Academy of Marketing Science, Vol. 45 No. 3, pp. 428-451.

Menon, A., and Varadarajan, P. R. (1992), “A model of marketing knowledge use within firms", Journal of Marketing, Vol. 56, pp. 53-71.

Michaelis, B., Stegmaier, R. and Sonntag, K. (2010), "Shedding light on followers' innovation implementation behavior: The role of transformational leadership, commitment to change, and climate for initiative", Journal of Managerial Psychology, Vol. 25 No. 4, pp. 408-429.

Miracle, Q. J., Ellinger, E. A. and Franke, R. G. (2018), "Work design and frontline employee engagement", Journal of Service Theory and Practice, Vol. 28 No. 5, pp. 636-660.

Moorman, C., Zaltman, G. and Deshpande, R. (1992), "Relationships between providers and users of market research: The dynamics of trust", Journal of Marketing Research, Vol. 29 No. 3, 314-328.

Morgan, R. M. and Hunt, S. D. (1994), "The commitment-trust theory of relationship marketing”, The Journal of Marketing, Vol. 58 No. July, pp. 20-38.

Morrison E. W. and Phelps, C. C. (1999), "Taking charge at work: Extrarole efforts to initiate workplace change", Academy of Management Journal, Vol. 42 No. 4, pp. 403-419.

Mujeri, M. K. and Younus, S. (2009), “An analysis of interest rate spread in the banking sector in Bangladesh", The Bangladesh Development Studies, pp. 1-33.

Mulinge, M. and Mueller, C. W. (1998), "Employee job satisfaction in developing countries: the case of Kenya", World Development, Vol. 26 No. 12, pp. 2181-2199.

Pansari, A. and Kumar, V. (2017), "Customer engagement: the construct, antecedents, and consequences", Journal of the Academy of Marketing Science, Vol. 45 No. 3, pp. 294311.

Parihar, P., Dawra, J. and Sahay, V. (2019), "The role of customer engagement in the involvement-loyalty link", Marketing Intelligence \& Planning, Vol. 37 No. 1, pp. 66-79. 
Parker, S. K., Williams, H. M. and Turner, N. (2006), "Modeling the antecedents of proactive behavior at work", Journal of Applied Psychology, Vol. 91 No. 3, pp. 636-652.

Prentice, C. and Loureiro, S. M. C. (2018),"Consumer-based approach to customer engagement-The case of luxury brands", Journal of Retailing and Consumer Services, Vol. 43, pp. 325-332.

Pugh, S. D. (2001), "Service with a smile: Emotional contagion in the service encounter", Academy of Management Journal, Vol. 44 No. 5, pp. 1018-1027.

Qi, J. M., Ellinger, A. E. and Franke, G. R. (2018), "Work design and frontline employee engagement", Journal of Service Theory and Practice, Vol. 28 No. 5, pp.636-660.

Rabbanee, F. K., Ramaseshan, B., Wu, C. and Vinden, A. (2012), "Effects of store loyalty on shopping mall loyalty", Journal of Retailing and Consumer Services, Vol. 19 No. 3, pp. 271-278.

Ramaseshan, B., Ishak, A. and Rabbanee, F.K. (2013), "The role of marketing managers' commitment and involvement in marketing strategy implementation", Journal of Strategic Marketing, Vol. 21 No. 6, pp. 465-483.

Reinartz, W. J. and Kumar, V. (2003), “The impact of customer relationship characteristics on profitable lifetime duration", Journal of Marketing, Vol. 67 No. 1, pp. 77-99.

Reynoso, J., Kandampully, J., Fan, X. and Paulose, H. (2015), “Learning from socially driven service innovation in emerging economies", Journal of Service Management, Vol. 26 No. 1, pp. 156-176.

Rich, B. L., Lepine, J. A. and Crawford, E. R. (2010), “Job engagement: Antecedents and effects on job performance", Academy of Management Journal, Vol. 53 No. 3, pp. 617635.

Riddle, D. I. (1992), “Leveraging cultural factors in international service delivery”, Advances in Services Marketing and Management, Vol 15 No 1, pp. 297-322.

Roy, S. K., Balaji, M.S., Soutar, G., Lassar, W.M. and Roy, R. (2018a). “Customer engagement behavior in individualistic and collectivistic markets", Journal of Business Research, Vol. 86, pp.281-290.

Roy, S. K., Shekhar, V., Lassar, W. M. and Chen, T. (2018b), "Customer engagement behaviors: The role of service convenience, fairness and quality", Journal of Retailing and Consumer Services, Vol. 44, pp. 293-304. 
Rupp, D. E., Shao, R., Skarlicki, D. P., Paddock, E. L., Kim, T. Y. and Nadisic, T. (2018), "Corporate social responsibility and employee engagement: The moderating role of CSRspecific relative autonomy and individualism”, Journal of Organizational Behavior, Vol. 39 No.5, pp. 559-579.

Saks, A. M. (2006), “Antecedents and consequences of employee engagement”, Journal of Managerial Psychology, Vol. 21 No. 7, pp. 600-619.

Saks, A. M. and Gruman, J. A. (2014), "What do we really know about employee engagement?", Human Resource Development Quarterly, Vol. 25 No. 2, pp. 155-182.

Salanova, M., Agut, S. and Peiró, J. M. (2005), "Linking organizational resources and work engagement to employee performance and customer loyalty: the mediation of service climate", Journal of Applied Psychology, Vol. 90 No. 6, pp. 1217-1227.

Schaufeli, W. B. and Bakker, A. B. (2004), "Job demands, job resources and their relationship with burnout and engagement: A multi-sample study", Journal of Organizational Behavior, Vol. 25, No. 3, pp. 293-315.

Schaufeli, W. B., Salanova, M., González-Romá, V. and Bakker, A. B. (2002), "The measurement of engagement and burnout: A two sample confirmatory factor analytic approach", Journal of Happiness Studies, Vol. 3 No. 1, pp. 71-92.

Schneider, B., Macey, W. H., Lee, W. C. and Young, S. A. (2009), “Organizational service climate drivers of the American Customer Satisfaction Index (ACSI) and financial and market performance", Journal of Service Research, Vol. 12 No. 1, pp. 3-14.

Schneider, B., Smith, D. B., and Goldstein, H. W. (2000), "Attraction-selection-attrition: Toward a person- environment psychology of organizations," In Walsh, W.B., Craik, K. H. and Price, R. H. (Eds.), Person-Environment Psychology: New Directions and Perspectives (Vol. 2nd, pp. 61-85). Mahwah, NJ: Erlbaum.

Schuler, R. S. and Jackson, S. E. (1987), "Linking competitive strategies with human resource management practices", The Academy of Management Executive, Vol. 1, pp. 207-219.

Seijts, G. H. and Crim, D. (2006), "What engages employees the most or, the ten C's of employee engagement", Ivey Business Journal, Vol. 70 No. 4, pp. 1-5.

Sharma, P., Chen, I. S., and Luk, S. T. (2012), "Exploring the role of IND-COL as a moderator in the comprehensive service evaluation model," Journal of International Consumer Marketing, Vol. 24 No. 1-2, pp. 129-142. 
Sim, M. and Plewa, C. (2017) "Customer engagement with a service provider and context: An empirical examination", Journal of Service Theory and Practice, Vol. 27 Issue: 4, pp.854876.

Simbula, S. and Guglielmi, D. (2013), "I am engaged, I feel good, and I go the extra-mile: Reciprocal relationships between work engagement and consequences", Revista De Psicología Del Trabajo Y De Las Organizaciones, Vol. 29 No. 3, pp. 117-125.

Sirianni, N. J., Bitner, M. J., Brown, S. W. and Mandel, N. (2013), "Branded service encounters: Strategically aligning employee behavior with the brand positioning", Journal of Marketing, Vol. 77 No. 6, pp. 108-123.

So, K. K. F., King, C. and Sparks, B. (2014), "Customer engagement with tourism brands: Scale development and validation", Journal of Hospitality \& Tourism Research, Vol. 38 No. 3, pp. 304-329.

Sorenson, S. and Adkins, A. (2014), "Why customer engagement matters so much now", Gallup Business Journal. July 22. Retrieved from

http://www.gallup.com/businessjournal/172637/why-customer-engagementmatters.aspx.

Spector, P. E. (2003), "Individual differences in health and well-being in organizations", Health and safety in organizations: A multilevel perspective, San Francisco: Jossey-Bass. [SIOP Frontier Series], pp. 29-55.

Thomson, M., MacInnis, D. J. and Whan Park, C. (2005), "The ties that bind: Measuring the strength of consumers' emotional attachments to brands", Journal of Consumer Psychology, Vol. 15 No. 1, pp. 77-91.

Tremblay, M. and Simard, G. (2005), "La mobilisation du personnel: l'art d'établir un climat d'échanges favorable basé sur la réciprocité", Gestion, Vol. 30 No. 2, pp. 60-68.

Uddin, S. S. and Suzuki, Y. (2014), "The impact of competition on bank performance in Bangladesh: an empirical study", International Journal of Financial Services Management 2, Vol. 7 No. 1, pp. 73-94.

Van Doorn, J., Lemon, K. N., Mittal, V., Nass, S., Pick, D., Pirner, P. and Verhoef, P. C. (2010), "Customer engagement behavior: Theoretical foundations and research directions", Journal of Service Research, Vol. 13 No. 3, pp. 253-266. 
Vargo, S. L. and Lusch, R. F. (2004), "Evolving to a new dominant logic for marketing”, Journal of Marketing, Vol. 68 No. 1, pp. 1-17.

Verhoef, P. C., Reinartz, W. J. and Krafft, M. (2010), “Customer engagement as a new perspective in customer management", Journal of Service Research, Vol. 13 No. 3, pp. 247-252.

Vivek, S. D., Beatty, S. E., Dalela, V. and Morgan, R. M. (2014), “A generalized multidimensional scale for measuring customer engagement”, Journal of Marketing Theory and Practice, Vol. 22 No. 4, pp. 401-420.

Vivek, S. D., Beatty, S. E. and Morgan, R. M. (2012), “Customer engagement: Exploring customer relationships beyond purchase", Journal of Marketing Theory and Practice, Vol. 20 No. 2, pp. 122-146.

World Bank. (2017). The World Bank in Bangladesh. Retrieved October 24, 2018, from The World Bank at http://www.worldbank.org/en/country/bangladesh/overview

Youssef, Y. M. A., Johnston, W. J., AbdelHamid, T.A., Dakrory, M. I. and Seddick, M. G. S. (2018), "A customer engagement framework for a B2B context", Journal of Business \& Industrial Marketing, Vol. 33 No. 1, pp.145-152.

Zhong, L., Wayne, S. J. and Liden, R. C. (2016), “Job engagement, perceived organizational support, high-performance human resource practices, and cultural value orientations: A cross-level investigation”, Journal of Organizational Behavior, Vol. 37 No. 6, pp. 823844. 


\section{Appendices}

Table A: Literature summary on the drivers and consequences of EE

\begin{tabular}{|c|c|c|c|}
\hline $\begin{array}{l}\text { Author(s) } \\
\text { (Study type) }\end{array}$ & Industry; Country & Drivers of EE & Consequences of EE \\
\hline $\begin{array}{l}\text { Anaza and } \\
\text { Rutherford, } 2012 \\
\text { (Empirical) }\end{array}$ & $\begin{array}{l}\text { Cooperative } \\
\text { extension service; } \\
\text { USA }\end{array}$ & $\begin{array}{l}\text { Organisational } \\
\text { identification, employee- } \\
\text { customer identification, } \\
\text { customer orientation }\end{array}$ & N/A \\
\hline $\begin{array}{l}\text { Auh et al., } 2016 \\
\text { (Empirical) }\end{array}$ & $\begin{array}{l}\text { Banking service; } \\
\text { Taiwan }\end{array}$ & Burnout due to supervisor & $\begin{array}{l}\text { Customer service } \\
\text { performance }\end{array}$ \\
\hline $\begin{array}{l}\text { Bailey et al., } 2017 \\
\text { (Narrative synthesis) }\end{array}$ & --- ; --- & $\begin{array}{l}\text { Psychological states, job } \\
\text { design; leadership, } \\
\text { organizational and team } \\
\text { factors, and organizational } \\
\text { interventions }\end{array}$ & Performance, morale \\
\hline $\begin{array}{l}\text { Barrick et al., } 2015 \\
\text { (Empirical) }\end{array}$ & $\begin{array}{l}\text { Credit unions; } \\
\text { USA }\end{array}$ & $\begin{array}{l}\text { Motivating work designs, } \\
\text { HRM practices, leadership } \\
\text { behaviors }\end{array}$ & Firm performance \\
\hline $\begin{array}{l}\text { Beek et al., } 2012 \\
\text { (Empirical) }\end{array}$ & Healthcare; China & $\begin{array}{l}\text { Introjected regulation, } \\
\text { identified regulation, } \\
\text { intrinsic motivation, and } \\
\text { job resources }\end{array}$ & N/A \\
\hline $\begin{array}{l}\text { Breevaart et al., } \\
2016 \text { (Empirical) }\end{array}$ & $\begin{array}{l}\text { Healthcare; } \\
\text { Netherlands }\end{array}$ & $\begin{array}{l}\text { Transformational } \\
\text { leadership, and employee } \\
\text { self-leadership }\end{array}$ & $\begin{array}{l}\text { Leader-rated job } \\
\text { performance }\end{array}$ \\
\hline $\begin{array}{l}\text { Crawford et al., } \\
2010 \\
\text { (Meta-analysis) }\end{array}$ & --- ; --- & $\begin{array}{l}\text { Challenge demands, } \\
\text { hindrance demands, job } \\
\text { resources }\end{array}$ & N/A \\
\hline $\begin{array}{l}\text { Demerouti et al., } \\
\text { 2001a } \\
\text { (Empirical) }\end{array}$ & $\begin{array}{l}\text { Insurance service; } \\
\text { Germany }\end{array}$ & Job demand, job control & $\mathrm{N} / \mathrm{A}$ \\
\hline $\begin{array}{l}\text { Demerouti et al., } \\
2001 \mathrm{~b} \\
\text { (Empirical) }\end{array}$ & $\begin{array}{l}\text { Education, } \\
\text { healthcare, } \\
\text { manufacturing, } \\
\text { and transport; } \\
\text { Germany }\end{array}$ & $\begin{array}{l}\text { Job resources (feedback, } \\
\text { reward, participation, job } \\
\text { control, job security, } \\
\text { supervisor support) }\end{array}$ & N/A \\
\hline $\begin{array}{l}\text { Dollard and Bakker, } \\
2010 \\
\text { (Empirical) }\end{array}$ & $\begin{array}{l}\text { Education service; } \\
\text { Australia }\end{array}$ & Job resources (job control) & N/A \\
\hline $\begin{array}{l}\text { Eldor and Harpaz, } \\
2016 \text { (Empirical) }\end{array}$ & $\begin{array}{l}\text { Technology, } \\
\text { Financial, and } \\
\text { Service }\end{array}$ & Perceived learning climate & $\begin{array}{l}\text { Extra-role } \\
\text { performance } \\
\text { (Proactivity, } \\
\text { knowledge sharing, } \\
\text { creativity, adaptivity) }\end{array}$ \\
\hline
\end{tabular}




\begin{tabular}{|c|c|c|c|}
\hline $\begin{array}{l}\text { Ghosh et al., } 2014 \\
\text { (Empirical) }\end{array}$ & $\begin{array}{l}\text { Banking service; } \\
\text { India }\end{array}$ & $\begin{array}{l}\text { Distributive justice, } \\
\text { procedural justice, } \\
\text { Interactional justice }\end{array}$ & N/A \\
\hline $\begin{array}{l}\text { Gruman and Saks, } \\
2011 \\
\text { (Conceptual) }\end{array}$ & --- ; --- & $\begin{array}{l}\text { Engagement facilitation, } \\
\text { performance agreement, } \\
\text { appraisal and feedback }\end{array}$ & $\begin{array}{l}\text { Improved } \\
\text { performance }\end{array}$ \\
\hline $\begin{array}{l}\text { Harter et al., } 2002 \\
\text { (Meta-analysis) }\end{array}$ & --- ; --- & Employee satisfaction & $\begin{array}{l}\text { Customer satisfaction, } \\
\text { productivity, } \\
\text { profitability, and } \\
\text { employee retention. }\end{array}$ \\
\hline $\begin{array}{l}\text { He et al., } 2019 \\
\text { (Empirical) }\end{array}$ & $\begin{array}{l}\text { Luxury brand; } \\
\text { China }\end{array}$ & Admiration & N/A \\
\hline $\begin{array}{l}\text { Karatepe et al., } 2018 \\
\text { (Empirical) }\end{array}$ & $\begin{array}{l}\text { Hotels' service; } \\
\text { Cyprus }\end{array}$ & $\begin{array}{l}\text { Management commitment } \\
\text { to service quality, stress, } \\
\text { personal resource (customer } \\
\text { orientation) }\end{array}$ & $\begin{array}{l}\text { Job outcomes (In-role } \\
\text { and extra-role job } \\
\text { performance, turnover } \\
\text { intentions) }\end{array}$ \\
\hline $\begin{array}{l}\text { Kumar and Pansari, } \\
2016 \\
\text { (Empirical) }\end{array}$ & B2B service; USA & $\mathrm{N} / \mathrm{A}$ & $\begin{array}{l}\text { Customer } \\
\text { engagement, firm } \\
\text { performance }\end{array}$ \\
\hline $\begin{array}{l}\text { Kwon et al., } 2016 \\
\text { (Conceptual) }\end{array}$ & --- ; --- & $\begin{array}{l}\text { Perceived employee voice, } \\
\text { employee experience, } \\
\text { (Supervisor-subordinate } \\
\text { relationship) }\end{array}$ & N/A \\
\hline $\begin{array}{l}\text { Lee and Ok, } 2015 \\
\text { (Empirical) }\end{array}$ & Hotel service; USA & $\begin{array}{l}\text { Core self-evaluations, } \\
\text { psychological climate } \\
\text { (Customer orientation, } \\
\text { internal service, managerial } \\
\text { support, information \& } \\
\text { communication) }\end{array}$ & N/A \\
\hline $\begin{array}{l}\text { Liu et al., } 2017 \\
\text { (Empirical) }\end{array}$ & $\begin{array}{l}\text { Restaurants' service; } \\
\text { USA }\end{array}$ & $\begin{array}{l}\text { Perceived organisational } \\
\text { support }\end{array}$ & Intent to leave \\
\hline $\begin{array}{l}\text { Lyu et al., } 2016 \\
\text { (Empirical) }\end{array}$ & $\begin{array}{l}\text { Hotel service; } \\
\text { China }\end{array}$ & Abusive supervision & $\begin{array}{l}\text { Customer-oriented } \\
\text { organizational } \\
\text { citizenship behavior } \\
\text { (OCB) }\end{array}$ \\
\hline $\begin{array}{l}\text { Menguc et al., } 2013 \\
\text { (Empirical) }\end{array}$ & $\begin{array}{l}\text { Clothing, footwear } \\
\text { and accessories; } \\
\text { Canada }\end{array}$ & $\begin{array}{l}\text { Supervisory support, } \\
\text { supervisory feedback }\end{array}$ & $\begin{array}{l}\text { Service employee } \\
\text { performance }\end{array}$ \\
\hline $\begin{array}{l}\text { Menguc et al., } 2017 \\
\text { (Empirical) }\end{array}$ & $\begin{array}{l}\text { Health care service; } \\
\text { Turkey }\end{array}$ & $\begin{array}{l}\text { Personal resource (self- } \\
\text { efficacy), Job resource (job } \\
\text { autonomy) }\end{array}$ & $\begin{array}{l}\text { Customer service } \\
\text { performance }\end{array}$ \\
\hline $\begin{array}{l}\text { Miracle et al., } 2018 \\
\text { (Empirical) }\end{array}$ & $\begin{array}{l}\text { Different service } \\
\text { industries; USA }\end{array}$ & $\begin{array}{l}\text { Staffing, standardization, } \\
\text { work variety, empowerment }\end{array}$ & N/A \\
\hline $\begin{array}{l}\text { Rich et al., } 2010 \\
\text { (Empirical) }\end{array}$ & Fire service; USA & $\begin{array}{l}\text { Value congruence, } \\
\text { perceived organizational } \\
\text { support, core self- } \\
\text { evaluations }\end{array}$ & $\begin{array}{l}\text { Task performance, } \\
\text { organizational } \\
\text { citizenship behavior }\end{array}$ \\
\hline $\begin{array}{l}\text { Rupp et al., } 2018 \\
\text { (Empirical) }\end{array}$ & $\begin{array}{l}\text { General business; } \\
\text { Canada, China, } \\
\text { France, Hong }\end{array}$ & Employee CSR perceptions & N/A \\
\hline
\end{tabular}




\begin{tabular}{llll}
\hline & $\begin{array}{l}\text { Kong, and } \\
\text { Singapore }\end{array}$ & \\
\hline $\begin{array}{l}\text { Salanove } \text { et al., 2005 } \\
\text { (Empirical) }\end{array}$ & $\begin{array}{l}\text { Hotels and } \\
\text { restaurants; --- }\end{array}$ & $\begin{array}{l}\text { Organizational resources } \\
\text { (Training, autonomy, } \\
\text { technology) }\end{array}$ & Service climate \\
\hline $\begin{array}{l}\text { Zhong } \text { et al., } 2016 \\
\text { (Empirical) }\end{array}$ & $\begin{array}{l}\text { 130 companies; } \\
\text { China }\end{array}$ & $\begin{array}{l}\text { High-performance HR } \\
\text { practices, perceived } \\
\text { organizational support }\end{array}$ & $\begin{array}{l}\text { In-role performance, } \\
\text { organizational } \\
\text { citizenship behavior } \\
\text { (OCB), intent to quit }\end{array}$ \\
\hline $\begin{array}{l}\text { The current study } \\
\text { Empirical })\end{array}$ & $\begin{array}{l}\text { Retail banking; } \\
\text { Bangladesh }\end{array}$ & $\begin{array}{l}\text { Climate for initiative, } \\
\text { climate for psychological } \\
\text { safety }\end{array}$ & Customer engagement \\
\hline
\end{tabular}


Table B: Literature summary on the drivers and consequences of CE

\begin{tabular}{|c|c|c|c|}
\hline $\begin{array}{l}\text { Author(s) } \\
\text { (Study type) }\end{array}$ & Industry; Country & Drivers of $\mathbf{C E}$ & Consequences of $\mathbf{C E}$ \\
\hline $\begin{array}{l}\text { Beckers et al., } 2018 \\
\text { (Empirical) }\end{array}$ & $\begin{array}{l}---; \text { USA, Europe } \\
\text { and Asia }\end{array}$ & N/A & $\begin{array}{l}\text { Abnormal stock return } \\
\text { (shareholder value) }\end{array}$ \\
\hline $\begin{array}{l}\text { Boardman et al., } \\
2018 \text { (Empirical) }\end{array}$ & $\begin{array}{l}\text { University education } \\
\text { services; Australia }\end{array}$ & $\begin{array}{l}\text { Envy reflex, consumer } \\
\text { perceived positional value }\end{array}$ & $\mathrm{N} / \mathrm{A}$ \\
\hline $\begin{array}{l}\text { Brodie et al., } 2011 \\
\text { (Conceptual) }\end{array}$ & --- ; --- & $\begin{array}{l}\text { Involvement, } \\
\text { participation, satisfaction }\end{array}$ & $\begin{array}{l}\text { Satisfaction, self-brand } \\
\text { connection, brand } \\
\text { attachment, brand } \\
\text { loyalty }\end{array}$ \\
\hline $\begin{array}{l}\text { Dwivedi, } 2015 \\
\text { (Empirical) }\end{array}$ & Mobile phone; India & $\mathrm{N} / \mathrm{A}$ & Loyalty intentions \\
\hline $\begin{array}{l}\text { Gopalakrishna et } \\
\text { al., } 2017 \\
\text { (Empirical) }\end{array}$ & B2B tradeshows; USA & $\begin{array}{l}\text { Tradeshow design, } \\
\text { tradeshow promotions }\end{array}$ & $\begin{array}{l}\text { Satisfaction, } \\
\text { behavioural outcomes } \\
\text { (purchase intention and } \\
\text { intention to return) }\end{array}$ \\
\hline $\begin{array}{l}\text { Gupta et al., } 2018 \\
\text { (Empirical) }\end{array}$ & $\begin{array}{l}\text { Consumer packaged } \\
\text { goods, financial services, } \\
\text { telecommunications, } \\
\text { hospitality, high } \\
\text { technology, and airlines; } \\
\text { US, UK, Germany, } \\
\text { Netherlands, Italy, } \\
\text { France, Slovenia, China, } \\
\text { India, Japan, Turkey, } \\
\text { and Australia }\end{array}$ & Emotions, satisfaction & $\begin{array}{l}\text { Tangible (firm } \\
\text { performance), } \\
\text { intangible (opt-in, } \\
\text { privacy sharing, } \\
\text { relevant marketing); }\end{array}$ \\
\hline $\begin{array}{l}\text { Harmeling et al., } \\
2017 \text { (Empirical) }\end{array}$ & $\begin{array}{l}\text { Community events; } \\
\text { USA }\end{array}$ & $\begin{array}{l}\text { Product experience } \\
\text { (performance, brand } \\
\text { associations), } \\
\text { psychological ownership, } \\
\text { self-transformation }\end{array}$ & $\begin{array}{l}\text { Firm performance } \\
\text { (revenue benefits, cost } \\
\text { savings) }\end{array}$ \\
\hline $\begin{array}{l}\text { Harrigan et al., } 2017 \\
\text { (Empirical) }\end{array}$ & Tourism; USA & Consumer involvement & $\begin{array}{l}\text { Behavioural intention } \\
\text { of loyalty }\end{array}$ \\
\hline $\begin{array}{l}\text { Harrigan et al., } 2018 \\
(\text { Empirical) }\end{array}$ & Tourism; USA & Consumer involvement & $\begin{array}{l}\text { Self-brand connection, } \\
\text { brand usage intent }\end{array}$ \\
\hline $\begin{array}{l}\text { Heinonen, } 2018 \\
\text { (Empirical) }\end{array}$ & $\begin{array}{l}\text { Family-related } \\
\text { magazines }\end{array}$ & $\begin{array}{l}\text { Behavior (community } \\
\text { changes, ease of use, } \\
\text { routines, etc.), emotions } \\
\text { (irritation, inspiration, } \\
\text { entertainment, etc.), } \\
\text { cognition (subjectivity, } \\
\text { brand familiarity, } \\
\text { relevance, etc.) }\end{array}$ & $\mathrm{N} / \mathrm{A}$ \\
\hline
\end{tabular}




\begin{tabular}{|c|c|c|c|}
\hline $\begin{array}{l}\text { Hollebeek et al., } \\
2014 \\
\text { (Empirical) }\end{array}$ & $\begin{array}{l}\text { Social networking sites } \\
\text { (Facebook, Twitter and } \\
\text { LinkedIn); } \\
---\end{array}$ & Consumer involvement & $\begin{array}{l}\text { Self-brand connection, } \\
\text { brand usage intent }\end{array}$ \\
\hline $\begin{array}{l}\text { Hollebeek et al., } \\
2019 \\
\text { (Conceptual) }\end{array}$ & --- ; --- & $\begin{array}{l}\text { Customer resource } \\
\text { integration, customer } \\
\text { knowledge sharing and } \\
\text { learning }\end{array}$ & $\begin{array}{l}\text { Customer co-creation, } \\
\text { Customer individual } \\
\text { and interpersonal } \\
\text { operant resource } \\
\text { development }\end{array}$ \\
\hline $\begin{array}{l}\text { Jaakkola and } \\
\text { Alexander, } 2014 \\
\text { (Empirical) }\end{array}$ & Rail service; Scotland & $\begin{array}{l}\text { Focal firm-related access, } \\
\text { ceding control, focal } \\
\text { customer-related } \\
\text { ownership, need for } \\
\text { improvements, } \\
\text { relationship and } \\
\text { communication, other } \\
\text { stakeholder-related } \\
\text { support }\end{array}$ & $\begin{array}{l}\text { Positive recognition, } \\
\text { improved experiences, } \\
\text { and community } \\
\text { regeneration }\end{array}$ \\
\hline $\begin{array}{l}\text { Kumar and Pansari, } \\
2016 \text { (Empirical) }\end{array}$ & B2B services; USA & Employee engagement & Firm performance \\
\hline $\begin{array}{l}\text { Marino and Presti, } \\
2018 \text { (Empirical) }\end{array}$ & $\begin{array}{l}\text { Fashion, food, tourism, } \\
\text { e-commerce; Italy }\end{array}$ & N/A & $\begin{array}{l}\text { Customer satisfaction, } \\
\text { behavior-based CRM } \\
\text { performance }\end{array}$ \\
\hline $\begin{array}{l}\text { Maslowka et al., } \\
2016 \\
\text { (Conceptual) }\end{array}$ & --- ; --- & $\begin{array}{l}\text { Brand actions; other } \\
\text { actions (customers' } \\
\text { actions, customers' } \\
\text { inquiries, customers' } \\
\text { feedback, customers' } \\
\text { events) }\end{array}$ & $\begin{array}{l}\text { Satisfaction, loyalty, } \\
\text { customer lifetime value }\end{array}$ \\
\hline $\begin{array}{l}\text { Pansari and Kumar, } \\
2017 \text { (Conceptual) }\end{array}$ & --- ; --- & Satisfaction; emotions & $\begin{array}{l}\text { Firm performance, } \\
\text { Intangible benefits } \\
\text { such as opt-in and } \\
\text { privacy sharing. }\end{array}$ \\
\hline $\begin{array}{l}\text { Parihar et al., } 2019 \\
\text { (Empirical) }\end{array}$ & Online retail; India & $\begin{array}{l}\text { Involvement (risk } \\
\text { importance, risk } \\
\text { probability, sign, interest, } \\
\text { pleasure) }\end{array}$ & Loyalty \\
\hline $\begin{array}{l}\text { Prentice and } \\
\text { Loureiro, } 2018 \\
\text { (Empirical) }\end{array}$ & $\begin{array}{l}\text { Luxury fashion brand; } \\
\text { Portugal }\end{array}$ & Desire, social value & Subjective well-being \\
\hline $\begin{array}{l}\text { Roy et al., 2018a } \\
\text { (Empirical) }\end{array}$ & $\begin{array}{l}\text { Luxury hotel; Australia, } \\
\text { USA, India and China }\end{array}$ & $\begin{array}{l}\text { Cognitive trust, affective } \\
\text { trust, value in use }\end{array}$ & N/A \\
\hline $\begin{array}{l}\text { Roy et al., } 2018 \mathrm{~b} \\
\text { (Empirical) }\end{array}$ & $\begin{array}{l}\text { Mobile } \\
\text { telecommunication and } \\
\text { retail banking; India }\end{array}$ & $\begin{array}{l}\text { Perceived quality, service } \\
\text { convenience, perceived } \\
\text { fairness }\end{array}$ & N/A \\
\hline $\begin{array}{l}\text { Sim and Plewa, } \\
2017 \\
(\text { Empirical })\end{array}$ & Universities; Australia & $\begin{array}{l}\mathrm{C} 2 \mathrm{C} \text { engagement } \\
\text { platforms }\end{array}$ & N/A \\
\hline $\begin{array}{l}\text { So et al., } 2014 \\
\text { (Empirical) }\end{array}$ & $\begin{array}{l}\text { Hotel and airline; } \\
\text { Australia }\end{array}$ & $\begin{array}{l}\text { Involvement, } \\
\text { interactivity, rapport, }\end{array}$ & $\begin{array}{l}\text { Behavioural intention } \\
\text { of loyalty }\end{array}$ \\
\hline
\end{tabular}


customer satisfaction,

commitment, trust, brand

attachment, and brand

performance perceptions

Customer-based (e.g.

Van Doorn et al., trust, identity, etc.), firm-

2010 (Conceptual) --- ; ---

based (e.g. reputation,

size, etc.), context-based

(e.g. competition)

Customer-based (e.g., identity), firm-based

(e.g., financial), others

(e.g., social surplus)

Customer characteristics,

Verhoef et al., firm initiatives,

2010

--- ; ---

environment

(Conceptual)

(competitive and economic climate)

Satisfaction,

Customer retention, customer equity, new product performance, firm value

Youssef et al., 2018

(Conceptual)

$---;---$

commitment, trust,

Customer equity: value

involvement

equity, brand equity, relationship equity

The current study

Retail banking;

(Empirical)

Bangladesh

Employee engagement

Relationship

commitment, and switching intention 
Figure 1: Conceptual framework

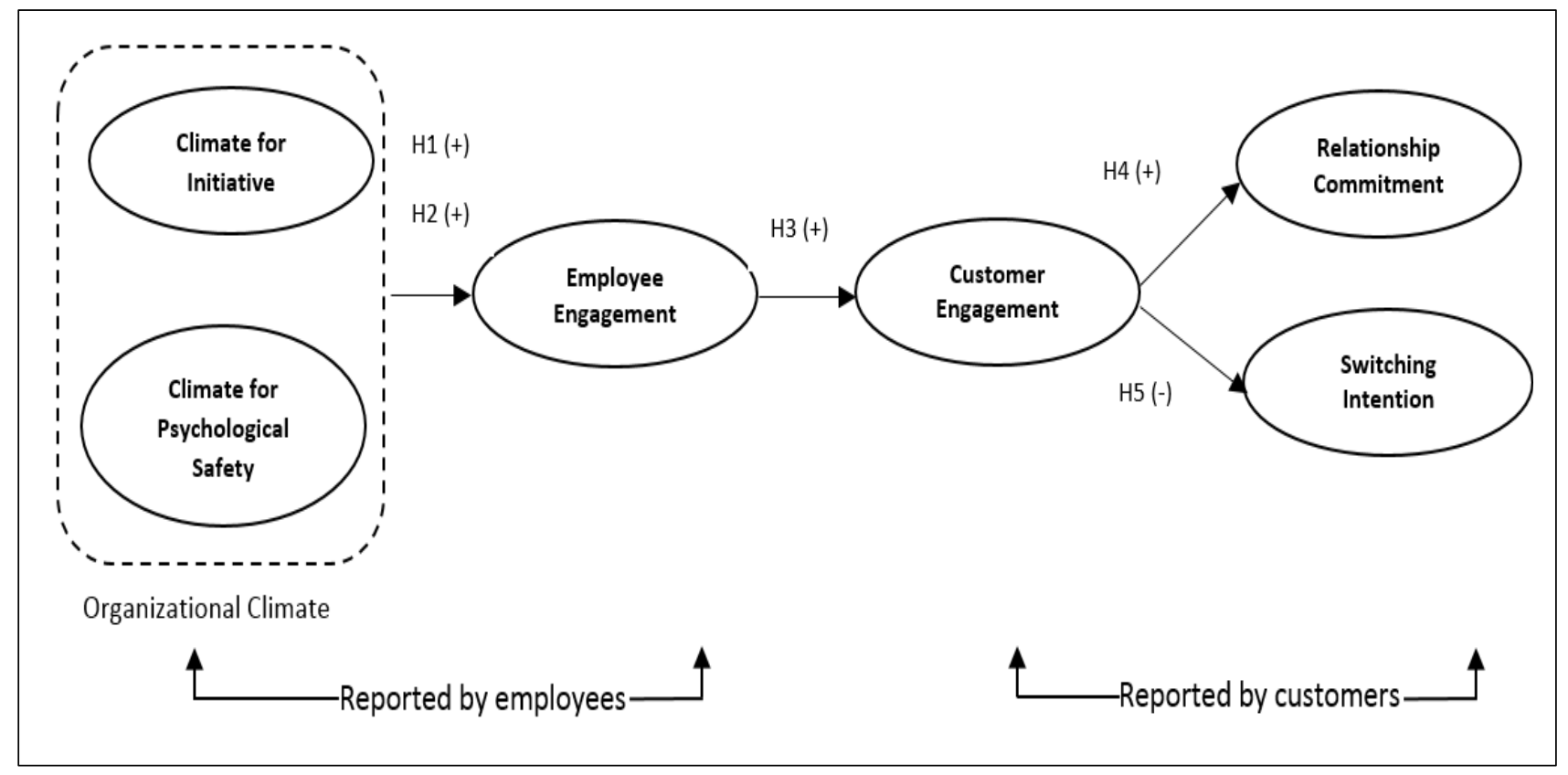


Table 1: Descriptive statistics of the constructs

\begin{tabular}{|c|c|c|c|}
\hline Constructs & Loading & Mean & SD \\
\hline \multicolumn{4}{|l|}{ Climate for Initiative: $[\alpha=0.85]$} \\
\hline Employees in this bank actively deal problems, if any. & 0.66 & 5.69 & 1.04 \\
\hline $\begin{array}{l}\text { Whenever something goes wrong, employees in this bank search for } \\
\text { a solution immediately. }\end{array}$ & 0.68 & 5.81 & 0.84 \\
\hline $\begin{array}{l}\text { Whenever there is a chance to get actively involved, employees of } \\
\text { this bank take it. }\end{array}$ & 0.82 & 5.63 & 0.92 \\
\hline $\begin{array}{l}\text { Employees in this bank take initiative immediately - more often } \\
\text { than in other banks. }\end{array}$ & 0.69 & 5.54 & 0.80 \\
\hline $\begin{array}{l}\text { Employees in this bank use opportunities quickly in order to attain } \\
\text { goals. }\end{array}$ & 0.79 & 5.76 & 0.82 \\
\hline \multicolumn{4}{|l|}{ Climate for Psychological Safety: $[\alpha=0.72]$} \\
\hline $\begin{array}{l}\text { When someone in our bank makes a mistake, it is often held against } \\
\text { them. (r) }\end{array}$ & 0.61 & 3.70 & 1.28 \\
\hline It is difficult to ask others for help in our bank.(r) & 0.59 & 5.20 & 0.77 \\
\hline Employees of this bank value others' skill and talents. & 0.69 & 5.11 & 0.95 \\
\hline $\begin{array}{l}\text { As an employee of this bank, we are able raise problems and tough } \\
\text { issues. }\end{array}$ & 0.59 & 4.91 & 0.99 \\
\hline \multicolumn{4}{|l|}{ Employee Engagement: } \\
\hline \multicolumn{4}{|l|}{ Vigour $[\alpha=0.83]$} \\
\hline At work, I feel full of energy. & 0.53 & 5.43 & 0.70 \\
\hline In my job, I feel strong and vigorous. & 0.52 & 5.51 & 0.73 \\
\hline When I get up in the morning, I feel like going to work. & 0.55 & 5.11 & 0.88 \\
\hline I can continue working for very long periods at a time. & 0.50 & 5.12 & 0.80 \\
\hline In my job, I am mentally very resilient. & 0.84 & 5.58 & 0.93 \\
\hline At work, I always persevere, even when things do not go well. & 0.84 & 5.59 & 0.92 \\
\hline \multicolumn{4}{|l|}{ Dedication $[\alpha=0.89]$} \\
\hline I find the work that I do full of meaning and purpose. & 0.67 & 5.86 & 0.68 \\
\hline I am enthusiastic about my job. & 0.95 & 5.60 & 1.23 \\
\hline My job inspires me. & 0.84 & 5.18 & 1.05 \\
\hline I am proud of the work I do. & 0.74 & 5.41 & 1.00 \\
\hline \multicolumn{4}{|l|}{ Absorption $[\alpha=0.91]$} \\
\hline Time flies when I'm working. & 0.81 & 5.44 & 1.32 \\
\hline When I am working, I forget everything else around me. & 0.65 & 4.99 & 1.62 \\
\hline I feel happy when I am working intensely. & 0.88 & 5.47 & 1.21 \\
\hline I am immersed in my work. & 0.83 & 5.40 & 1.10 \\
\hline I get carried away when I'm working. & 0.71 & 4.94 & 1.03 \\
\hline It is difficult to detach myself from my job. & 0.78 & & \\
\hline \multicolumn{4}{|l|}{ Customer Engagement: } \\
\hline $\begin{array}{l}\text { Conscious Attention }[\alpha=0.86] \\
\text { Anything related to this bank grabs my attention. }\end{array}$ & 0.87 & 5.56 & 1.09 \\
\hline
\end{tabular}


I pay a lot of attention to anything about this bank.

I get involved to learn more about this bank.

Cognitive Engagement $[\alpha=0.95]$

While using banking products and services I think about this bank.

I think about this bank a lot when I use its products and services.

Using this bank's products and services stimulates my interest to learn more about the bank.

Affective Engagement $[\alpha=0.94]$

I feel very positive when I use this bank's products and services.

Using products and services from this bank makes me happy.

I feel good when I use products and services of this bank.

I feel proud to use products and services of this bank.

Enthused Participation $[\alpha=0.85]$

I spend a lot of time in this bank compared to other similar banks.

Whenever I need any banking products and service, I usually buy from this bank.

I enjoy buying banking products and services from this bank.

Relationship Commitment: [ $\alpha=0.94]$

The relationship that I have with this bank is something I am very committed to.

The relationship that I have with this bank is something very important to me.

The relationship that I have with this bank is something I intend to maintain indefinitely.

The relationship that I have with this bank is something that I really care about.

The relationship that I have with this bank deserves my maximum effort to maintain.

Switching Intention: $[\alpha=0.92]$

Please rate the probability that you would switch from this bank within next 12 months:
i) Unlikely Likely
ii) Impossible Possible
iii) No chance Certain

Note: $\alpha=$ Cronbach's alpha; SD = Standard Deviation;

0.88


Table 2 - Psychometric properties of the constructs

\begin{tabular}{|c|c|c|c|c|c|c|c|c|c|c|c|}
\hline & CI & $\mathrm{CP}$ & VR & $\mathrm{DN}$ & $\mathrm{AN}$ & $\mathrm{CA}$ & $\mathrm{CE}$ & $\mathrm{AE}$ & EP & $\mathrm{RC}$ & SW \\
\hline Climate for Initiative (CI) & 1 & & & & & & & & & & \\
\hline Climate for Psy. Safety (CP) & $0.37 * *$ & 1 & & & & & & & & & \\
\hline Vigor (VR) & $0.41 * *$ & $0.60 * *$ & 1 & & & & & & & & \\
\hline Dedication (DN) & $0.41 * *$ & $0.52 * *$ & $0.76^{* *}$ & 1 & & & & & & & \\
\hline Absorption (AN) & $0.25 * *$ & -0.01 & $0.46^{* *}$ & $0.60 * *$ & 1 & & & & & & \\
\hline Conscious Attention (CA) & $0.28 * *$ & 0.06 & $0.41 * *$ & $0.61 * *$ & $0.63 * *$ & 1 & & & & & \\
\hline Cognitive Engagement (CE) & $0.26^{* *}$ & $0.22 * *$ & $0.54 * *$ & $0.74 * *$ & $0.70^{* *}$ & $0.76^{* *}$ & 1 & & & & \\
\hline Affective Engagement (AE) & $0.25 * *$ & $0.19 * *$ & $0.50 * *$ & $0.71 * *$ & $0.65 * *$ & $0.73 * *$ & $0.84 * *$ & 1 & & & \\
\hline Enthused Participation (EP) & $0.27 * *$ & $0.24 * *$ & $0.49 * *$ & $0.69 * *$ & $0.60 * *$ & $0.75^{* *}$ & $0.78 * *$ & $0.77 * *$ & 1 & & \\
\hline R. Commitment (RC) & $0.29 * *$ & 0.09 & $0.45^{* *}$ & $0.62 * *$ & $0.66^{* *}$ & $0.73^{* *}$ & $0.74 * *$ & $0.71^{* *}$ & $0.67 * *$ & 1 & \\
\hline Switching intention (SW) & $-0.30 * *$ & $-0.12 *$ & $-0.43 * *$ & $-0.62 * *$ & $-0.63 * *$ & $-0.60 * *$ & $-0.67 * *$ & $-0.64 * *$ & $-0.58^{* *}$ & $-0.66^{* *}$ & 1 \\
\hline $\mathrm{CR}$ & 0.90 & 0.80 & 0.86 & 0.93 & 0.94 & 0.92 & 0.97 & 0.97 & 0.91 & 0.97 & 0.96 \\
\hline AVE & 0.66 & 0.50 & 0.53 & 0.76 & 0.65 & 0.80 & 0.92 & 0.89 & 0.77 & 0.86 & 0.89 \\
\hline
\end{tabular}

Note: ${ }^{* *}=>p<0.01 ; *=>p<0.05 ; A V E=$ Average variance extracted; $C R=$ composite reliability 
Table 3: Standardized coefficients, $t$-value, and $t$-value of the structural model

\begin{tabular}{lcccc}
\hline \multicolumn{1}{c}{ Particulars } & $\begin{array}{c}\boldsymbol{\beta}- \\
\text { value }\end{array}$ & $\begin{array}{c}\boldsymbol{t}- \\
\text { value }\end{array}$ & Decision \\
\hline H1: Climate for initiative $=>$ Employee engagement & 0.22 & 4.05 & Supported \\
H2: Climate for psychological safety $=>$ Employee engagement & 0.46 & 5.28 & Supported \\
H3: Employee engagement $=>$ Customer engagement & 0.84 & 14.34 & Supported \\
H4: Customer engagement $=>$ Relationship commitment & 0.85 & 16.96 & Supported \\
H5:Customer engagement $=>$ Switching intention & -0.78 & -15.14 & Supported \\
\hline
\end{tabular}

